\author{
Federal Reserve Bank of Dallas \\ Globalization and Monetary Policy Institute \\ Working Paper No. 196 \\ http://www.dallasfed.org/assets/documents/institute/wpapers/2014/0196.pdf
}

\title{
Real Exchange Rates and Sectoral Productivity in the Eurozone*
}

\author{
Martin Berka \\ University of Auckland \\ Michael B. Devereux \\ University of British Columbia \\ NBER and CEPR \\ Charles Engel \\ University of Wisconsin
}

September 2014

\begin{abstract}
We investigate the link between real exchange rates and sectoral total factor productivity measures for countries in the Eurozone. Real exchange rate patterns closely accord with an amended Balassa-Samuelson interpretation, both in cross-section and time series. We construct a sticky price dynamic general equilibrium model to generate a cross-section and time series of real exchange rates that can be directly compared to the data. Under the assumption of a common currency, estimates from simulated regressions are very similar to the empirical estimates for the Eurozone. Our findings contrast with previous studies that have found little relationship between productivity levels and the real exchange rate among high-income countries, but those studies have included country pairs which have a floating nominal exchange rate.
\end{abstract}

JEL codes: F41, F31

\footnotetext{
* Martin Berka, Department of Economics, University of Auckland, 6th Floor, Owen G. Glenn Building, 12 Grafton Road, Private Bag 92019, Auckland 1142, New Zealand. 64-9-923-8985. m.berka@auckland.ac.nz. Michael B. Devereux, Vancouver School of Economics, University of British Columbia, NBER and CEPR. 997-1873 East Mall, Vancouver, BC, Canada, V 6T1Z1. devm@mail.ubc.ca. Corresponding author is Engel. Devereux's research is supported by ESRC Award Number ES/I024174/1 and SSHRC. Engel acknowledges research support from National Science Foundation grant no. 1226007. The authors would like to thank discussants at the conference on Exchange Rates and External Adjustment, CEPR and SNB, Zurich, August 2012; the RBNZ; Hitotsubashi University; the conference on Renminbi and Global Economy, CUHK, May 2013; the 5th Bi-Annual Bank of Canada/ECB conference on 'Exchange Rates: A Global Perspective', ECB, Frankfurt, June 2013; The Bank of Canada Annual Research Conference, November 2013; the Bank of France; UC Irvine; Penn State University; University of Kyoto; the Missouri Economics Conference, March 2014; the ABFER Conference, Singapore 2014; the Shefield Workshop in Macroeconomics, May 2014; and the XXIX Annual Economic Meeting, Central Bank of Uruguay, August 2014. The views in this paper are those of the authors and do not necessarily reflect the views of the Federal Reserve Bank of Dallas or the Federal Reserve System.
} 


\section{Introduction}

Prices of consumer goods differ substantially across countries, and vary considerably between any two countries over time. In the aggregate, relative goods prices compared across countries are defined as real exchange rates. The central theoretical framework for interpreting real exchange rates is the Balassa-Samuelson model, in which persistent movements in real exchange rates over time and across countries are driven by cross-country differentials in sectoral total factor productivities. Yet it is widely acknowledged that the Balassa-Samuelson model does not do well in explaining real exchange rates (e.g. Chinn and Johnston, 1996, Rogoff, 1996, Tica and Družić, 2006, Lothian and Taylor, 2008, Chong, Jordà and Taylor, 2012) except over very long time horizons. In most empirical studies, especially in time series data, the evidence for the effect of productivity growth on real exchange rates is quite weak. This problem is especially apparent in the study of real exchange rate movements among high-income, financially developed countries with floating exchange rates.

This paper revisits the investigation of real exchange rate determination using a new data set of European price levels at a disaggregated level. The price data covers a large group of European countries, it has a very broad coverage, encompassing almost the whole consumer basket, and it has an extremely high degree of crosscountry comparability. Our sample of European countries allows us to construct a panel of real exchange rates at the sectoral and aggregate level in a large number of European countries over the period 1995-2009. Since the data is in levels we can construct a real exchange rate distribution across countries at any point in time, and track the movement of this distribution over time.

Our particular focus is the properties of real exchange rates in the Eurozone, where bilateral nominal exchange rates are fixed. It is well known from the literature on open economy macroeconomics that floating nominal exchange rates are influenced by monetary policy decisions and shocks, financial shocks, and quite possibly also by non-fundamental shocks. When nominal prices adjust more slowly than the nominal exchange rate, these shocks also influence the real exchange rate. Our working hypothesis is that the real exchange rate among countries that share a common currency 
is more fertile ground for finding evidence of the Balassa-Samuelson effect because the short-run real exchange rate movements are not driven by these monetary and financial factors that influence nominal exchange rates.

We combine our panel of real exchange rates with measures of sectoral total factor productivities for each country, as well as a separate measure of unit labor costs. We then conduct panel regressions of real exchange rates to explore the link between the real exchange rates and productivity. Our empirical results indicate that for the Eurozone countries, there is substantial evidence of an amended Balassa-Samuelson effect. An increase in total factor productivity in traded goods is associated with a real appreciation, and an increase in total factor productivity in non-traded goods correlates with a real depreciation. But these links appear only when we separately control for unit labor cost differentials across countries. We find that, holding productivity constant, higher unit labor costs lead to real exchange rate appreciation. One interpretation for this phenomenon is that there are separate institutional forces driving factor prices, independent of factor productivities. In our theoretical model, we allow for this channel by introducing shocks to labor supply that are unrelated to productivity.

The Balassa-Samuelson model must be modified when the exports of a country are not perfect substitutes for its imports (e.g. Fitzgerald, 2003). We show in a simple flexible-price model how differences in unit labor costs may influence real exchange rates both through their effects on the relative prices of non-traded goods and also the terms of trade. We have noted that the Balassa-Samuelson effect may be difficult to find when nominal exchange rates are volatile and goods prices are sticky. We proceed to examine the implications for the Balassa-Samuelson theory when nominal exchange rates are not volatile, since countries share a common currency, but nominal prices are sticky. We construct a small dynamic general equilibrium model of real exchange rates, with sticky prices and monetary policy under fixed exchange rates. We can use the model to generate a panel of real exchange rate levels and movements over time which matches the European panel for the Eurozone countries. Using the same crosssection and time series dimensions as the data, the model is simulated using shocks to sectoral productivities and labor supply shocks. We find a close relationship between 
the empirical estimates and the model simulation estimates. Real exchange rates in the model are driven by an amended Balassa-Samuelson pattern of shocks to sectoral productivity and unit labor costs, and the simulation estimates are extremely close to those in the Eurozone data. We find that a sticky price version of the model, where $20 \%$ of prices change every quarter, best explains the empirical estimates. Although a fully flexible price version of our model does quite a good job in explaining the empirical results, it tends to predict movements in real exchange rates in response to traded sector productivity and unit labor costs that are too large relative to the empirical estimates.

The paper is related to a large literature on the explanation of secular movements in real exchange rates. A central prediction of many theoretical models (including, but not restricted to the Balassa-Samuelson model) is that the cross-country distribution of real exchange rates should be related to relative GDP per capita. High income countries should have stronger (more appreciated) real exchange rates. Rogoff (1996), for example, uses relative GDP per capita as a proxy for the relative productivity in the traded sector. Rogoff finds in cross-sectional 1990 data that includes poor and rich countries, a strong relationship between relative GDP per capita and the real exchange rate.11 However, Rogoff then notes "... whereas the relationship between income and prices is quite striking over the full data set, it is far less impressive when one looks either at the rich (industrialized) countries as a group, or at developing countries as a group". In particular, among high-income countries with floating exchange rates, there is little evidence of a relationship between GDP per capita and the real exchange rate.

The Balassa-Samuelson theory suggests real exchange rates should be related to sectoral total factor productivity (TFP) rather than income levels, as in the Rogoff study. There are few studies that examine the cross-sectional dimension of the Balassa-Samuelson hypothesis using sectoral data on TFP, because most TFP data that is used for cross-country comparisons is in index form and is only useful for look-

\footnotetext{
${ }^{1}$ Bergin, Glick, and Taylor (2006) note that this cross-sectional relationship has strengthened over time, and suggests that the tradability of goods is endogenous and may increase as a sectors productivity grows.
} 
ing at the time-series dimension. The evidence favorable to the Balassa-Samuelson effect is much weaker in the time-series dimension. A number of studies have looked at the relationship between productivity and real exchange rates, but in most cases can report only evidence of a long run relationship such as cointegration. Thus, Chinn and Johnston (1996) use measures of total factor productivity, and find that when controlling for other variables such as government expenditure, there is evidence of cointegration of the real exchange rate and the relative productivity variable for 14 OECD countries ${ }^{2}$ Canzoneri, et. al. (1996) find cointegration between relative labor productivities and the real exchange rate for a panel of OECD countries. Lee and Tang (2007) examine the effect of sectoral productivity growth in a panel of OECD economies with floating exchange rates, and find conflicting evidence for the impact of labor productivity as opposed to TFP on the real exchange rate. Their results provide only mild support for the traditional Balassa-Samuelson mechanism. Gubler and Sax (2011) find no evidence at all for the Balassa-Samuelson prediction. They argue that OECD real exchange rates tend to move in the opposite direction to Balassa-Samuelson in response to sectoral TFP differentials $3^{3}$

A notable finding of some of these papers (e.g. De Gregorio et al. (1994), Canzoneri et al (1996), Lee and Tang (2007)) is that there is often stronger evidence of the effect of relative sectoral productivity on internal, within-country relative prices than can be found in between-country real exchange rates. This may be due to the presence of nominal exchange rate fluctuations that have little to do with relative productivity differentials. Again, this suggests to us that a focus on real exchange rate determination in a sample where nominal exchange rate movement is absent or minimized may be a fruitful avenue of investigation.

Two recent studies examine nonlinear convergence models of the real exchange rate, relating it to relative income per capita. Lothian and Taylor (2008) use 180 years of data to find a long-run relationship between relative per capita income levels and

\footnotetext{
${ }^{2}$ De Gregorio et. al. (1994) use the same TFP data and country coverage as Chinn and Johnston to examine the dynamics of the prices of nontradable relative to tradable goods.

${ }^{3}$ Hsieh and Klenow (2007) relate the Balassa-Samuelson model to the well-known finding that the price of investment goods tends to be higher in poorer countries. Using ICP-Penn World Tables data they find that poorer countries have lower TFP in the tradable-investment sector than in the non-tradable consumption sector, leading to lower prices of consumption goods in these countries.
} 
real exchange rates among the U.S., U.K. and France. Chong et. al. (2010) examine the real exchange rates of 21 OECD countries from 1973-2008. That study uses nonlinear time series techniques to purge real exchange rates of short-run monetary and financial factors, and then finds a link between relative income per capita levels and long-run real exchange rates.

Bordo et. al. (2014) find a long-run relationship between relative income and real exchange rates in a panel of fourteen countries relative to the U.S. with a sample of over 100 years of data, allowing for a time trend which they argue captures changing trade costs. Chen et. al. (2014) document a building block of the Balassa-Samuelson hypothesis. They find that in the cross section of prices provided in the International Comparison Project, the relative price of non-traded goods accounts for two-thirds of the cross-sectional variation in real exchange rates. Choudri and Schembri (2014) extend the Balassa-Samuelson model to allow for differentiated products in exports, and then find time-series support for a long-run relationship between sectoral productivity and the real exchange rate in accounting for the Canada-U.S. real exchange rate.

The channel through which relative productivity levels influence real exchange rates is their effect on the relative price of non-traded goods. Engel (1999) produces evidence that little of the variance of changes in U.S. real exchange rates can be accounted for by the relative price of non-traded goods. Almost all of the variance arises from movements in the consumer prices of traded goods in the U.S. relative to other countries. Several studies (e.g., Devereux 1999, Engel, 1999, Burstein et. al. 2003, 2005, Betts and Kehoe, 2006) suggest that differences in consumer prices of traded goods across countries may be accounted for by changes in the relative price of non-traded distribution services, but the evidence for this hypothesis is weak for highincome countries. However, the seminal paper by Mussa (1986) documents a number of differences between the behavior of real exchange rates in countries with fixed nominal exchange rates versus countries that have floating rates. Among these are the significantly higher volatility of real exchange rates under floating. Our findings in this paper are striking evidence against nominal exchange regime neutrality (using Mussas famous phrase.) 
As mentioned above, the price level data we use in the paper is unique and of very high quality. One major advantage of our study, relative to many papers in the literature, is that the price data has both a broad coverage, governing the complete consumer basket in the Eurozone countries studied, and has a very high degree of cross country comparability. In Section 3 of the paper below, as well as an extensive data Appendix, we describe the construction of the data, and emphasize the extensive set of procedures that Eurostat follows to ensure that goods in each of the categories are measuring very similar products across countries.

The second unique feature of our data is an annual panel of sectoral TFP levels across nine Eurozone countries. This TFP data allow us to make cross-sectional comparisons, as well as the time comparisons, across sectors and countries. To our knowledge, this is the first time that a sectoral TFP panel in levels has been used to study real exchange rate determination and the Balassa-Samuelson hypothesis.

The paper is organized as follows. The next section sets out a basic theoretical model of real exchange rates with shocks to productivity and labor supply, and derives a simple analytical example of the link between real exchange rates, productivity, and unit labor costs. Section 3 outlines our data, and shows some properties of European real exchange rates for the Eurozone and non-Eurozone countries. This section also describes the properties of sectoral productivity and unit labor costs for a restricted sample of countries. We provide empirical estimates of an amended Balassa-Samuelson relationship for the Eurozone. Section 4 calibrates the theoretical model, and performs the same regressions on simulated data as were done with the Eurozone data. Some conclusions follow.

\section{Real Exchange Rates in a Theoretical Model}

\subsection{A Basic New Keynesian model}

Our data is a balanced panel of European countries' real exchange rates. In the model simulations, we construct a panel of equivalent dimensions. But the theoretical explication of the model can be developed using the standard two-country DSGE approach. Let these countries be called 'Home' and 'Foreign'. We primarily present 
equations for Home. Equations for the Foreign country are symmetric to those for Home, and Foreign variables are denoted with a $*$

The utility of a representative infinitely lived Home country household evaluated from date 0 is defined as:

$$
U_{t}=E_{0} \sum_{t=0}^{\infty} \beta^{t}\left(\frac{C_{t}^{1-\sigma}}{1-\sigma}-\Upsilon_{t} \frac{N_{t}^{1+\psi}}{1+\psi}\right), \quad \beta<1 .
$$

where $C_{t}$ in (1) is the composite Home consumption bundle, and $N_{t}$ is Home labor supply. We allow that the disutility in labor supply $\Upsilon_{t}$ to be time-varying and countryspecific. This plays a role in generating real exchange rate variability across countries and over time, as described below. The composite consumption good is defined as:

$$
C_{t}=\left(\gamma^{\frac{1}{\theta}} C_{T t}^{1-\frac{1}{\theta}}+(1-\gamma)^{\frac{1}{\theta}} C_{N t}^{1-\frac{1}{\theta}}\right)^{\frac{\theta}{\theta-1}}
$$

where $C_{T t}$ and $C_{N t}$ represent, respectively, the composite consumption of traded and non-traded goods. The elasticity of substitution between traded and non-traded goods is $\theta$. Traded consumption in turn is decomposed into consumption of Home retail goods, and Foreign retail goods, as follows:

$$
C_{T t}=\left(\omega^{\frac{1}{\lambda}} C_{H t}^{1-\frac{1}{\lambda}}+(1-\omega)^{\frac{1}{\lambda}} C_{F t}^{1-\frac{1}{\lambda}}\right)^{\frac{\lambda}{\lambda-1}}
$$

where $\lambda$ is the elasticity of substitution between the Home and Foreign traded good. Home households put weight $\omega$ on Home consumption goods in their consumption basket. In the Foreign country, households put weight $\omega$ on Foreign consumption goods. In a perfectly symmetric model, there would be no home bias in consumption if $\omega=1 / 2$, but the stronger the preference of households for the good produced in their own country, the larger is $\omega$.

Retail consumption of traded goods requires the use of non-traded goods in order to facilitate consumption, however. ${ }^{4}$ This can be rationalized by the argument that

\footnotetext{
${ }^{4}$ The importance of distribution costs in real exchange rate determination has been emphasized in the literature on exchange rate pass-through. See for example Burstein, et al. (2003). Engel (1999) investigates the link between distribution costs and traded consumer prices in accounting for real exchange rate volatility. The role of a distribution sector in regards to the predictions of the Balassa-Samuelson model has been emphasized theoretically by Devereux (1999) and empirically by Macdonald and Ricci (2005).
} 
there are costs of distribution of traded goods, and these costs must be incurred by local (i.e. non-traded inputs). Hence, we assume that the production of consumptionrelated retail goods in sectors $H$ and $F$ are assembled according to:

$$
\begin{aligned}
C_{H t} & =\left(\kappa^{\frac{1}{\phi}} I_{H t}^{1-\frac{1}{\phi}}+(1-\kappa)^{\frac{1}{\phi}} V_{H t}^{1-\frac{1}{\phi}}\right)^{\frac{\phi}{\phi-1}} \\
C_{F t} & =\left(\kappa^{\frac{1}{\phi}} I_{F t}^{\left(1-\frac{1}{\phi}\right)}+(1-\kappa)^{\frac{1}{\phi}} V_{F t}^{1-\frac{1}{\phi}}\right)^{\frac{\phi}{\phi-1}}
\end{aligned}
$$

where $I_{H t}$ represents inputs of the Home export good into the retail consumption of that good, and $V_{H t}$ represents input of the Home non-traded good into the retail consumption of the export good. The elasticity of substitution between non-traded inputs and the export good itself is $\phi$. Our calibrations in section 4 will set $\phi$ to be fairly low, representing the fact that distribution services are not a good substitute for the actual consumption good. The notation for the retail consumption of imports (Foreign goods) is similarly defined.

The consumption aggregates imply the following price index definitions:

$$
\begin{gathered}
P_{t}=\left(\gamma P_{T t}^{1-\theta}+(1-\gamma) P_{N t}^{1-\theta}\right)^{\frac{1}{1-\theta}} \\
P_{T t}=\left(\omega \tilde{P}_{H t}^{1-\lambda}+(1-\omega) \tilde{P}_{F t}^{1-\lambda}\right)^{\frac{1}{1-\lambda}}
\end{gathered}
$$

where $P_{T t}$ and $P_{N t}$ represent traded and non-traded price levels, and $\tilde{P}_{H t}$ and $\tilde{P}_{F t}$ are retail prices of consumption of Home and Foreign traded goods. Finally, these retail prices in turn depend on prices at the dock as well as the non-traded goods price. Hence:

$$
\begin{aligned}
\tilde{P}_{H t} & =\left(\kappa P_{H t}^{(1-\phi)}+(1-\kappa) P_{N t}^{1-\phi}\right)^{\frac{1}{1-\phi}} \\
\tilde{P}_{F} & =\left(\kappa P_{F t}^{(1-\phi)}+(1-\kappa) P_{N t}^{1-\phi}\right)^{\frac{1}{1-\phi}}
\end{aligned}
$$

We assume that prices of goods at the dock are equal in the Home and Foreign countries in the Eurozone, so that:

$$
P_{H t}=P_{H t}^{*}, \quad P_{F t}=P_{F t}^{*}
$$


The real exchange rate, however, may not be a constant because of prices of nontraded consumption goods and distribution services are not equalized across the Home and Foreign countries, and because of the possibility that consumption baskets differ. We define the real exchange rate as the price of Foreign relative to Home consumption

$$
Q_{t}=\frac{P_{t}^{*}}{P_{t}}
$$

Note that the nominal exchange rate between the Home and Foreign country is fixed at one because countries in the Eurozone share a common currency.

We assume that international financial markets are complete. As is well known, this implies a risk sharing condition given by:

$$
\frac{C_{t}^{-\sigma}}{P_{t}}=\frac{C_{t}^{*-\sigma}}{P_{t}^{*}}
$$

Households choose consumption of individual goods and labor supply in each sector in the usual way. The implicit labor supply for Home households is given by:

$$
W_{t}=\Upsilon_{t} P_{t} C^{\sigma} N_{t}^{\psi}
$$

where $W_{t}$ is the nominal wage. The demand for traded and non-traded goods is described as:

$$
C_{T t}=\gamma\left(\frac{P_{T t}}{P_{t}}\right)^{-\theta} C_{t}, \quad C_{N t}=(1-\gamma)\left(\frac{P_{N t}}{P_{t}}\right)^{-\theta} C_{t}
$$

Demand for Home and Foreign composite traded Goods is denoted as:

$$
C_{H t}=\omega\left(\frac{\tilde{P}_{H t}}{P_{T t}}\right)^{-\lambda} C_{T t}, \quad C_{F t}=(1-\omega)\left(\frac{\tilde{P}_{F t}}{P_{T t}}\right)^{-\lambda} C_{T t}
$$

We can express the individual consumption demand for Home and Foreign traded goods (net of the distribution services) as

$$
I_{H t}=\kappa \omega\left(\frac{P_{H t}}{\tilde{P}_{H t}}\right)^{-\phi}\left(\frac{\tilde{P}_{H t}}{P_{T t}}\right)^{-\lambda} C_{T t}, \quad I_{F t}=\kappa(1-\omega)\left(\frac{P_{F t}}{\tilde{P}_{F t}}\right)^{-\phi}\left(\frac{\tilde{P}_{F t}}{P_{T t}}\right)^{-\lambda} C_{T t},
$$

Firms in each sector produce using labor and a fixed capital stock. 5 A typical firm in the non-traded (traded) sector has production function $Y_{N t}(i)=A_{N t} N_{N t}(i)^{\alpha}$,

\footnotetext{
${ }^{5}$ The implications for real exchange rates would not differ materially were we to allow for endogenous capital accumulation.
} 
$Y_{H t}(i)=A_{H t} N_{H t}(i)^{\alpha}$. Thus, there are two technology shocks - shocks to the nontraded sector $A_{N t}$, and to the traded sector $A_{H t}$. In addition to the labor supply shock $\Upsilon_{t}$, these shocks are the key fundamental driving forces of equilibrium real exchange rates in the model.

With perfectly flexible prices, assuming that each firm is a monopolistic competitor with constant elasticity of substitution between varieties within each sub-sector, a firm in the Home country would set its price equal to marginal cost, adjusted by a constant markup. Thus, for the typical non-traded goods firm and a Home traded goods producing firm, we have, in a flexible price environment:

$$
P_{N t}^{\text {flex }}=\Omega \frac{W_{t}}{\alpha A_{N t} L_{N t}^{\alpha-1}}, \quad P_{H t}^{\text {flex }}=\Omega \frac{W_{t}}{\alpha A_{H t} L_{H t}^{\alpha-1}}
$$

where $\Omega$ is a constant markup, depending on the elasticity of substitution between varieties.

We assume that firms cannot reset prices freely, but rather must follow a Calvo price adjustment specification where the probability of the firm being allowed to adjust its price is $1-\zeta_{i}$, where $i=N, F$. Home firms use domestic household nominal marginal utilities as stochastic discount factors. When prices are reset, firms set their price so that it is equal to a discounted present value of current and anticipated future fully flexible prices:

$$
\begin{aligned}
& P_{N t}=\frac{E_{t} \sum_{\tau=t}^{\infty} \Gamma_{N, \tau} P_{N \tau}^{f l e x}}{E_{t} \sum_{\tau=t}^{\infty} \Gamma_{N, \tau}} \\
& P_{H t}=\frac{E_{t} \sum_{\tau=t}^{\infty} \Gamma_{H, \tau} P_{H \tau}^{f l e x}}{E_{t} \sum_{\tau=t}^{\infty} \Gamma_{H, \tau}}
\end{aligned}
$$

where $\Gamma_{N, t}$ and $\Gamma_{H, t}$ represent adjusted stochastic discount factors that incorporate the Calvo probability of a firm's price staying constant each period. Foreign firms price Foreign exports, $P_{F t}^{*}$ and Foreign non-traded goods, $P_{N t}^{*}$, analogously.

The countries of the Eurozone share a common monetary policy. The instrument of monetary policy is the nominal interest rate, and we assume the central bank follows an inflation targeting instrument rule. For simplicity, we assume the central bank targets the inflation rate in the Foreign country:

$$
r_{t}=\rho+\sigma_{p} \pi_{t}^{*}
$$


where $\pi_{t}^{*}=p_{t}^{*}-p_{t-1}^{*}$ is the Foreign inflation rate (and $\left.p_{t}^{*}=\log \left(P_{t}^{*}\right)\right)$ [ In practice, in simulation results, we find it makes essentially no difference if the central bank targets the Home inflation rate, the Foreign inflation rate, or an average.

Finally, goods market clearing conditions are given as:

$$
\begin{aligned}
Y_{H t} & =I_{H t}+I_{H t}^{*} \\
Y_{F t}^{*} & =I_{F t}+I_{F t}^{*}, \\
Y_{N t} & =C_{N t}+V_{H t}+V_{F t}, \\
Y_{N t}^{*} & =C_{N t}^{*}+V_{H t}^{*}+V_{F t}^{*} .
\end{aligned}
$$

Traded goods production must equal demand derived from Home and Foreign consumers' consumption of retail traded goods. Non-traded goods production is equal to that accounted for by consumers, and that used in the distribution services of traded goods, in each country.

In addition, we must have labor market clearing in each country, so that:

$$
\begin{aligned}
& N_{t}=N_{N t}+N_{H t} \\
& N_{t}^{*}=N_{N t}^{*}+N_{H t}^{*}
\end{aligned}
$$

The definition of equilibrium is standard and we omit it to save space.

\subsection{The Real Exchange Rate Decomposition}

The real exchange rate in this model is determined both by structural differences across countries and time-varying shocks specific to individual countries. Thus, our perspective on real exchange rates requires an analysis of the determinants of both permanent (or highly persistent) relative price differentials across countries, as well as the movements over time in the bilateral real exchange rate for any pair of countries. Following Engel (1999), we can write a log linear approximation of the real exchange rate in terms of differences in the relative price of non-traded to traded goods across countries, and differences across countries in the price indexes of traded goods.

\footnotetext{
${ }^{6}$ In our empirical work, the Foreign country is the set of 15 members of the European Union, 12 of which are in the Eurozone. The assumption here that the Foreign inflation rate is targeted is meant to capture the notion that Eurozone inflation is targeted by the European Central Bank.
} 
Omitting time subscripts for ease of notation, we have:

$$
q=(1-\gamma) q_{n}+q_{T}
$$

where $q_{n} \equiv\left(p_{N}^{*}-p_{T}^{*}-\left(p_{N}-p_{T}\right)\right)$, and $q_{T} \equiv p_{T}^{*}-p_{T}$.

The first expression on the right hand side is the difference across countries in the relative local currency price of non-traded to traded goods. A rise in the Foreign relative price, relative to the Home relative price, causes a Home real exchange rate depreciation. The second expression on the right hand side is the traded goods real exchange rate at the retail level. But in our model, due to distribution costs in retail, this should also be affected by the relative price of non-traded goods. To see this, we may further decompose the second expression as:

$$
q_{T}=\frac{1-\kappa}{\kappa} q_{n}+(2 \omega-1) \tau+p_{H}^{*}-p_{H}
$$

where $\tau=p_{F}^{*}-p_{H}^{*}=p_{F}-p_{H}$ is the terms of trade of the Home country and $p_{H}^{*}-p_{H}$ represents the deviation from the law of one price in Home traded goods. This expression tells us that the traded goods real exchange rate is driven by a) differences in relative non-traded goods prices across countries - again a rise in this relative-relative price will cause a real exchange rate depreciation, b) the terms of trade, when there is home bias in preferences (i.e. $\omega>\frac{1}{2}$ ), and c) deviations from the law of one price - a higher Foreign price of equivalent goods relative to the Home price is associated with a real exchange rate depreciation.

The model of CES demand under monopolistic competition that we outlined above does not allow for any explicit price-discrimination across countries by producers. Hence there is no 'pricing-to-market' by sellers. Moreover, because our analysis is restricted to countries within a single currency area, if prices are pre-set, they are all done so within a single currency. This implies that the 'law of one price' must apply for equivalent goods across countries. Hence $P_{H}^{*}=P_{H}\left(\right.$ and also $\left.P_{F}^{*}=P_{F}\right)$. Therefore, our model of the Eurozone allows for real exchange rates to be determined either by movements across countries in non-traded goods prices, or by variations in the terms of trade. 


\subsection{Relative Productivity and Real Exchange Rates}

The decomposition above tells us what the channels of real exchange determination will be, but it is silent on the underlying determinants of real exchange rates. Our empirical investigation goes beyond this and links the real exchange rate to the fundamental shocks introduced in the theoretical model. Here we provide a special case of the model in order to motivate this link. The centrepiece of the mechanism driving the real exchange rate is the presence of sectoral productivity movements. The BalassaSamuelson effect captures the link between relative productivity in traded to nontraded goods sectors and the real exchange rate. The standard Balassa-Samuelson mechanism implies that a rise in relative traded goods productivity causes a rise in the relative price of non-traded to traded goods (when compared across countries), leading to a real exchange rate appreciation. But when Home and Foreign goods are not perfect substitutes there is a countervailing effect coming from the endogenous response of the terms of trade. A rise in relative Home traded goods productivity would be expected to generate a terms of trade deterioration. Conditional on the relative price of non-traded goods to domestic goods in each country, the terms of trade deterioration will lead the real exchange rate to depreciate. In addition, though, we have introduced a labor supply shock $\Upsilon$. This will also affect the real exchange rate in our model. In fact, here we show that these types of shocks are of critical importance in introducing a separate role for unit labor costs as distinct from sectoral productivities as drivers of the real exchange rate. 7

To illustrate the argument, we take a special case of the model, where a) $\omega=\frac{1}{2}$, so that there is no home bias, b) $\alpha=1$, so that output is linear in labor input and c) $\zeta_{i}=0$, so that all prices are perfectly flexible. As in the previous subsection, take a log-linear approximation around a symmetric steady state. Without home bias into retail goods the real exchange rate is just the ratio of non-traded prices across countries. Hence from (7) and (8) we have:

$$
q=(1-\gamma \kappa)\left(p_{N}^{*}-p_{N}\right)
$$

\footnotetext{
${ }^{7}$ Much of the discussion of the evolution of real exchange rates in Europe has focused on the role of unit labor costs. Felipe and Kumar (2011) indeed document that differences in unit labor costs in the Eurozone are highly correlated with the relative price of output $\left(p_{F}^{*}-p_{H}\right.$ above).
} 
where the term $\gamma \kappa$ indicates that non-traded goods prices influence the real exchange rate both directly, through the price of consumer non-traded goods, and indirectly, through the distribution cost of traded goods 8

Now if prices are fully flexible, and output is linear in labor, we have $p_{N}=w-a_{N}$, where $w$ is the $\log$ of the Home nominal wage, and $a_{N}$ is the log of Home productivity in the non-traded sector. Since this holds equally for the Foreign country, the real exchange rate then becomes:

$$
q=(1-\gamma \kappa)\left(w^{*}-a_{N}^{*}-\left(w-a_{N}\right)\right)
$$

Note that since labor is mobile across sectors, and profit maximization holds in the traded goods sector, we must have $w^{*}-w=p_{F}^{*}-p_{H}+\left(a_{F}-a_{H}\right)$. Thus, 10 becomes

$$
q=(1-\gamma \kappa)\left(p_{F}^{*}-p_{H}+\left(a_{F}^{*}-a_{H}\right)-\left(a_{N}^{*}-a_{N}\right)\right)
$$

This expression separates the real exchange rate into the components driven by relative non-traded goods productivity, relative traded goods productivity, and the terms of trade component $p_{F}^{*}-p_{H}$. The classical Balassa Samuelson model assumes that the terms of trade are constant, so the real exchange rate depends only on relative productivity in the traded and non-traded goods sectors.

We may substitute out the terms of trade from (11) through the use of relative unit labor costs. We define unit labor cost for the Home country as the nominal wage divided by output per worker. Hence we have

$$
\mathrm{ulc}=w-\gamma \kappa\left(y_{H}-n_{H}\right)-(1-\gamma \kappa)\left(y_{N}-n_{N}\right)=w-\gamma \kappa a_{H}-(1-\gamma \kappa) a_{N}
$$

Using the definition of production with $\alpha=1$, and again using profit maximization in the traded goods sector, we have relative unit labor cost for Foreign to Home defined as:

$$
\text { rulc }=p_{F}^{*}-p_{H}+(1-\gamma \kappa)\left(a_{F}^{*}-a_{H}\right)-(1-\gamma \kappa)\left(a_{N}^{*}-a_{N}\right)
$$

Then substitute (12) into (11) to get

$$
q=(1-\gamma \kappa) \operatorname{rulc}+(1-\gamma \kappa) \gamma \kappa\left(a_{F}^{*}-a_{H}\right)-(1-\gamma \kappa) \gamma \kappa\left(a_{N}^{*}-a_{N}\right)
$$

\footnotetext{
${ }^{8}$ For simplicity, we have assumed that the distribution share is identical across countries and for domestic and imported goods.
} 
Equation (13) represents an amended Balassa-Samuelson model of the real exchange rate, where the condition controls for terms of trade movements through the use of relative unit labor costs. Conditional on relative unit labor costs, the real exchange rate is positively related to relative (Foreign vs. Home) traded goods productivity, and negatively to relative non-traded goods productivity. This equation underlies our empirical specification for the real exchange rate in section 3 below. It says that, given unit labor costs, the traditional Balassa-Samuelson mechanism will apply. A rise in Home traded productivity should lead to real exchange rate appreciation - while a rise in Home non-traded productivity should lead to real exchange rate depreciation.

But (13) also says that unit labor costs should appear as a separate driver of the real exchange rate. Conditional on sectoral productivity, a rise in relative unit labor costs in the Home country should lead to real exchange rate appreciation.

In condition (13), relative unit labor costs are endogenous. To see how they are related to the labor supply shocks in the model, we can take a separate but related decomposition of (11). In the case of complete security markets and assumptions a)-c), we can express the terms of trade in the following way (where $\chi \equiv \log (\Upsilon)$ ):

$$
\begin{gathered}
p_{F}^{*}-p_{H}=\sigma c+p-\sigma c^{*}-p^{*}+p_{F}^{*}-p_{H}= \\
w-\chi-\psi h-\left(w^{*}-\chi^{*}-\psi h^{*}\right)+p_{F}^{*}-p_{H}=\chi^{*}-\chi+\psi\left(h^{*}-h\right)+a_{H}-a_{F}^{*}
\end{gathered}
$$

where the first equality uses the risk-sharing condition (2), the second equality uses the labor supply conditions (2.1), and the third equality uses the flexible price profit maximizing condition for each country, with symmetry. This condition says that the Home country terms of trade under assumptions a)-c) and complete markets is negatively related to relative labor supply shocks, and positively related both to movements in relatively labor supply (or output), and relative traded good productivities. Substituting into (11) we get:

$$
q=(1-\gamma \kappa)\left(\chi^{*}-\chi+\psi\left(h^{*}-h\right)\right)-(1-\gamma \kappa)\left(a_{N}^{*}-a_{N}\right)
$$

Under these conditions, the real exchange rate depends only on relative labor supply shocks, relative total employment, and relative non-traded goods productivity. Labor 
supply shocks push up real wages, increasing relative non-traded goods prices. A rise in relative employment has an equivalent effect, since conditional on labor supply shocks and non-traded productivity, it must be associated with a rise in relative wages. A rise in non-traded goods productivity reduces relative non-traded prices and reduces the real exchange rate.

How does this relate to the basic Balassa-Samuelson condition? Here we see that traded goods productivity affects the real exchange rate only in so far as it affects total employment. If $\psi=0$, so that the labor supply curve is infinitely elastic, then the Balassa-Samuelson linkage from traded goods productivity to the real exchange rate disappears entirely. This is a case where the endogenous adjustment of the terms of trade to traded goods productivity completely offsets the direct effect of productivity shocks on the real exchange rate.

A comparison of (13) and (14) thus suggests that in the empirical specification for the Balassa-Samuelson test of real exchange rate determination, it is important to control for relative unit labor costs. This allows for the presence of labor supply shocks, and acts as an implicit control for movement in the terms of trade. As we see below, once we control for relative unit labor costs in this way, the Balassa-Samuelson model is strongly supported in the data.

In the more general model with sticky prices, the real exchange rate cannot be neatly expressed in the form of (13) or (14). Nevertheless, as shown below, even with the general specification that involves sticky prices, it is still important to allow a separate role for unit labor costs in a quantitative account of real exchange rate determination.

\section{Data: Real Exchange Rates and Productivity}

\subsection{Real Exchange Rates in European Data}

We describe the features of European real exchange rates based on disaggregated price data. The data are constructed by Eurostat, as part of the Eurostat PPP project. They are arranged in the form of 'Price Level Indices', or PLI's. A PLI gives the price of a good at a given time for a given country, relative to a reference country price. 
Hence, it is a good-specific PPP, although within the Eurozone, this measure does not involve different currencies. The reporting frequency is annual, over 1995-2009 and the PLI's are available for 146 "basic headings" of consumer goods and services. These include food (including food away from Home), clothing, housing costs, durable goods, transportation costs, as well as medical and educational services. They cover 100\% of the consumption basket. The full list of PLI's for the basic headings of consumer goods and services is contained in Table 1. For each item, the reference price is constructed as a ratio of the European average price of each good.9 Hence the prices are comparable in levels, so that both cross section and time series real exchange rate variation can be examined. Our sample data contains 11 countries that entered the Eurozone in 1999 ${ }^{10}$ and one that entered in 2001 (Greece) ${ }^{11}$ We construct aggregate and sectoral real exchange rates from the underlying price series, using expenditure weights. The expenditure weights are constructed using euro expenditures on every basic heading in every country and every year. Thus, the expenditure weights are time-varying, year by year ${ }^{12}$ Let $q_{i t}$ be the real exchange rate for country $i$ at time $t$, and let $q_{i T t}\left(q_{i N t}\right)$ represent the average real exchange rate for the subset of traded (non-traded) goods. As in the model, real exchange rates are measured so that an increase represents a depreciation 13

Relative to other studies that have compared price levels internationally, our price data has some distinct advantages. First, it is comprehensive, covering the entire consumer basket. This is in contrast to important recent studies that have used only prices from a single supermarket chain (for example, Gopinath, et. al. (2011),

\footnotetext{
${ }^{9}$ The average is taken over the 15 European Union countries given by: Austria, Belgium, Denmark, France, Germany, Greece, Ireland, Italy, Luxembourg, the Netherlands, Spain, Sweden, Portugal, Finland and the United Kingdom.

${ }^{10}$ These are Belgium, Germany, Spain, France, Ireland, Italy, Luxembourg, Netherlands, Austria, Portugal, and Finland.

${ }^{11}$ Note that our sample includes the period 1995-1998 before the official inception of the euro. But intra-Eurozone exchange rate fluctuations over this period were very small, with average quarterly standard deviations about 1 percent.

${ }^{12}$ We do not explicitly incorporate VAT differences, but Berka and Devereux (2013) show that there are only small differences in VAT across these European countries, and they change very little over the sample.

${ }^{13}$ Hence, $q_{i t}$ represents the inverse of the average price level for country $i$, relative to the European average.
} 
Burstein and Jaimovich (2012)), or from a single international retailer of household goods (Haskel and Wolf (2002) and Baxter and Landry (2012)), or from a small number of online retailers (Cavallo, et. al. (2014).) Some studies have used a more comprehensive selection of prices from the Economist Intelligence Unit survey (for example, Engel and Rogers (2004) or Crucini and Shintani (2008).) However, that data is not as comprehensive as the Eurostat data we use, but more importantly it does not strive for the degree of comparability across countries of goods and services that are priced. In the Appendix, we quote extensively from Eurostat-OECD PPP manual to help to convey the care and effort that is made to make these prices comparable. Here we mention only a few points. First, while Eurostat reports prices for 146 basic headings, within each heading are numerous subheadings for which prices are compared. For example, in the category other bakery products price comparisons are made for crispbread, rusks, toasted bread, biscuits, gingerbread, wafers, waffles, crumpets, muffins, croissants, cakes, tarts, pies, quiches and pizzas. For each of these items, an exhaustive effort is made to insure comparability of the goods that are priced. This project strives to price a product at the various types of outlets (for example, department store, supermarket, specialty outlet) in proportion to the share of national expenditure on the item that is made at each type of outlet. When prices from various similar outlets show higher variation within a country, more products are sampled.

We separate goods into traded and non-traded categories using criteria reported in the Appendix. Using these aggregate measures, some descriptive statistics are reported in Table 2. The Table first reports the average log real exchange rate over the sample for each country, denoted $\bar{q}$, as well as the equivalent measures for the traded goods real exchange rate $\bar{q}_{T}$, the non-traded goods real exchange rate, $\bar{q}_{N}$, and also the relative price of non-traded goods $\bar{q}_{n}=\bar{q}_{N}-\bar{q}_{T}$.

We see from the Table that Belgium, Germany and France have average real exchange rates close to zero, implying they are at the European average. Ireland and Finland have much lower real exchange rates, while Greece, Spain, Portugal and Italy, have much higher average real exchange rates. The characteristics of the sectoral real exchange rates, and the average relative price of non-traded goods closely mirror the 
aggregate real exchange rates. In general, we see that if for a given country $i$, we have $\bar{q}_{i}>0,(<0)$, we also have $\bar{q}_{T i}>0,(<0), \bar{q}_{N i}>0,(<0)$, and $\bar{q}_{N i}-\bar{q}_{T i}>0,(<0)$. That is, if a country has a low (high) average price level relative to the European average, its non-traded goods price tends to be proportionately lower (higher) than its traded goods price, relative to the average. This offers some initially encouraging evidence for a Balassa-Samuelson interpretation of real exchange rates, in the sense that differences across Eurozone countries in average real exchange rates are mirrored by differences in internal relative sectoral prices in a manner that is consistent with Balassa-Samuelson.

The second panel of Table 2 reports standard deviations of annual real exchange rates. They are approximately 3 percent for most countries. We would anticipate that the standard deviation of non-traded real exchange rates exceeds that of the traded real exchange rates. We find this to be true for 8 of the 12 Eurozone countries. For the other countries, the difference between the standard deviation across sectors is too small to report.

Table 3 reports averages across all countries and over time. For comparison purposes, we also include data from the non-Eurozone floating exchange rate high income European countries (these are Denmark, Iceland, Norway, Sweden, Switzerland and the UK) and a group of emerging market, mostly Eastern European countries (these are Cyprus, Czech Republic, Estonia, Hungary, Latvia, Lithuania, Malta, Poland, Slovakia, Slovenia, Bulgaria, Romania and Turkey for the RER data). The first panel gives the average time series volatility of aggregate and sectoral real exchange rates. The second panel reports the cross country dispersion in aggregate and sectoral real exchange rates. The high income floating exchange rate economies have substantially higher time series standard deviations of real exchange rates, roughly twice that of the Eurozone countries. For the Eastern European economies, time series standard deviations are about 3 times that of the Eurozone 14

The cross country dispersion of aggregate real exchange rates within the Eurozone

\footnotetext{
${ }^{14}$ Note that these are standard deviations of logs, rather than log differences. For the Eurozone and the floating exchange rate high income countries, there is little apparent trend in the real exchange rate over time. For many of the Eastern European countries, there is more of a clear trend downwards (towards appreciation) over the sample.
} 
is over 11 percent, about the same as that for the floating exchange rate countries. Table 3 suggests that the main difference between the Eurozone and the floating rate countries of Western Europe arises from the differences in their time-series standard deviations, which is quite intuitive. Measuring over all countries however, including the East European countries, the dispersion of real exchange rates is much larger; 33 percent for the aggregate real exchange rate and almost 50 percent for the nontraded real exchange rate. These high numbers in large part reflect the continuing high gap between price levels for the high income European economies and those of the emerging economies of Eastern Europe.

Figure 1 illustrates some properties of real exchange rates in the Eurozone. Panel a) shows the pattern of mean annual standard deviations of all consumer good PLI's for the Eurozone as a whole. If PPP held at the goods level, this would be zero

all the time. The Figure indicates that overall dispersion fell progressively over the sample. However, panels b)-d), charting the level and time path of national aggregate and sectoral real exchange rates, tells a somewhat different story. First, there is considerable persistence in real exchange rate differentials over the whole sample between the lowest and highest countries, and secondly, there is substantial movement over time in relative positions. For instance, Germany experienced substantial real depreciation from the beginning to the end of the sample, and Ireland and Italy displayed large real appreciation during the same time frame.

\subsection{Productivity and Unit Labor Cost data}

We compute measures of total factor productivity that match our real exchange rate sample. For this, we require TFP levels, both in the aggregate and by sector, for the same sample period as in the real exchange rate data. We do this by combining two sources for TFP. We construct a concordance between the sectors included in the Groningen Growth and Development Center's (GGDC thereafter) 1997 TFP level database, and the sectors included in the KLEMS time-series database. These two databases are meant to be used in conjunction, as described in Inklaar and Timmer (2008). Then, the cross-sectional TFP database and the time-series TFP database are linked using the constructed concordance to obtain annual sectoral panel TFP 
level data. We then use measures of the tradability of each sector and sectoral weights to construct level and time series of TFP for traded and non-traded sectors in each country. Following this, we organize the aggregate and sectoral TFP data so that they can be matched to their analogous real exchange rate measures: i.e. TFP in the EU relative to country $i$ TFP. As a result, we obtain a panel of traded and non-traded TFP levels which provide a match for our real exchange rate data 15 The details of the construction are in the Appendix A.

Table 2 and 3 report descriptive statistics for traded and non-traded goods productivity in the same form as the real exchange rate data. These data indicate that the Netherlands, Ireland and Finland have relatively high levels of traded goods TFP, while Spain, Italy and Austria have relatively low levels. In general, we see also that traded goods productivity is more volatile than non-traded goods productivity.

Apart from productivity shocks, we have introduced labor supply shocks as a separate driver of the real exchange rate, as measured by the variable $\chi$ above. We do not observe this variable in the data. However, if there are country specific labor supply related shocks, driven for instance by labor market institutions, unionization or regulatory changes, which are independent of productivity shocks, we should see this reflected in real wage movements that are not attributable to movements in aggregate or sectoral TFP. We capture this possibility by including unit labor costs as a separate variable in the regressions reported below. The theoretical justification for relating $\chi$ to unit labor costs was discussed in Section 2 above. Unit labor costs (ULC) are computed from the OECD Stat database, and expressed as average ULC in the EU17 relative to ULC in country $i$ (the same way as the sectoral productivity and real exchange rate data). Table 2 and 3 also report descriptive statistics on unit labor costs.

Figure 2 illustrates the properties of traded and non-traded productivity for the subset of countries in the categories of Figure 1 for which we have sectoral productivity data. Recall that a rise implies a fall in relative productivity, in order to have an

\footnotetext{
${ }^{15}$ The matching is not quite perfect, because only 9 of the 12 Eurozone countries in the sample have TFP data: Belgium, Germany, Spain, France, Ireland, Italy, the Netherlands, Austria, and Finland. We lack TFP data for Greece, Luxembourg, and Portugal.
} 
equivalent comparison with real exchange rates. The Figure indicates that there are substantial differences in both the average levels of sectoral productivity across the countries measured, as well as strongly asymmetric trends over the sample. Spain and Italy also deteriorate progressively over the sample period, while Finland and Austria improve systematically.

Figure 2c illustrates our measures of unit labor cost. Both in levels and movements over time, this is quite different from sectoral productivity, thus justifying our use of unit labor cost as a separate determinant of real exchange rates. At the beginning of the sample, Italy had low unit labor costs and Germany very high unit labor costs, but Italy's unit labor costs increase progressively in relative terms, while Germany's unit labor costs fall progressively. It is notable that the trend in Germany's unit labor cost is a lot more pronounced than that in its sectoral productivity.

\subsection{Real Exchange Rates, Relative Prices and Productivity}

In this section we describe a direct empirical investigation of the Balassa-Samuelson model using our constructs of sectoral real exchange rates, sectoral productivities, and unit labor costs. Tables 4 and 5 report the results of panel regressions on real exchange rates and various definitions of relative prices, as well as real exchange rates and productivity. For each of the empirical relationships we investigate here, we present four different approaches to handling the panel of data. In the first, we pool the data and estimate a simple ordinary least squares regression. In the second, we introduce a fixed effect for each country. This approach captures only the time-series relationship among variables within each country. The fixed effects approach does not allow us to take advantage of the fact that our unique price and productivity data allow us to make cross-country comparisons of the levels of real exchange rates and their explanatory variables. We consider a third approach that only takes account of the cross-sectional relationships. We average the variables over time for each country, and then estimate a cross-sectional OLS regression. Finally, we estimate a random effects model. Under random effects, the intercept term for each country may differ, but these intercept terms are assumed to be independent random variables. A wellknown property of the random effects estimator of the slope coefficients is that they 
are a weighted average of the fixed effect estimator and the cross-section estimator, where the weight on a given estimator is higher the greater its relatively explanatory power. As we will see, we tend to find strong support for the model using all four approaches.

A basic prediction of the Balassa-Samuelson model, captured also by the decomposition in (7), is that there should be positive relationship between the aggregate real exchange rate and the ratio of non-traded to traded goods prices. Table 4a indicates that this relationship is highly robust in the data for the 12 Eurozone countries. Moreover, this holds both for the pooled regressions, as well as the regressions with fixed or random effects. This finding contrasts strongly with a large literature on real exchange rates among floating exchange rate countries, where even at relatively low frequencies it is difficult to detect any clear relationship between relative non-traded goods prices and aggregate real exchange rates (e.g. Engel 1999).

Table $4 \mathrm{~b}$ explores the relationship between the traded goods real exchange rate and the relative price of non-traded goods, captured by the expression (8). In the presence of distribution costs in the traded goods sector (i.e. $\kappa<1$ ), this relationship should be positive. We see that this is true in the Eurozone data.

In the third panel (Table 4c), the one-to-one relationship between the traded goods real exchange rate and the overall real exchange rate, which is the second expression on the right hand side of (7), is strongly supported in both time series and cross section.

Table 5 reports the central empirical findings of our paper the relationship between the real exchange rate and its determinants, traded and non-traded total factor productivity and unit labor costs. Our preferred specification, which relates the real exchange rate to all three determinants as in equation (13), looks very good under all four empirical approaches (pooled, cross-section, fixed effects and random effects.) In every case in this specification, traded TFP enters with the correct sign and is significant at the 5 percent level. Unit labor costs also enter with the correct sign in every specification, and are significant at the 5 percent level. Non-traded TFP also takes on the correct sign under all four empirical approaches, and is significant at the 5 percent level in three of the four cases (while marginally insignificant in the 
cross-sectional regression.) As in the Balassa-Samuelson hypothesis, an increase in traded productivity tends to increase a countrys overall consumer price level (relative to the price level of the $\mathrm{EU}$ as a whole). An increase in non-traded productivity, on the other hand, is associated with a real depreciation. Also, holding productivity constant, an increase in unit labor costs raises the countrys relative consumer price level.

In the next section, we compare the magnitude of the coefficients in this regression to those predicted by our theoretical model. To presage our findings, the match is very close.

Table 5 also shows that the specifications that are less complete do not perform particularly well in accounting for real exchange rates in the Eurozone. When we try to explain the real exchange rate using only total TFP (without distinguishing between traded and non-traded TFP), and without controlling for unit labor costs, we find that there is a significantly positive association between TFP and the real exchange rate in the pooled and cross-sectional regressions, but very little association is found in the fixed-effects or random effects regressions. When we use sectoral (traded and non-traded) measures of productivity, but do not include unit labor costs as an explanatory variable, the results are mixed. In the pooled and cross-section regressions, traded productivity has the predicted sign and is significant, and in the fixed effects and random effects regressions, non-traded productivity is significant with the correct sign. But neither measure of productivity is significant in all the specifications that do not include unit labor costs.

We conclude that empirically there is support for the Balassa-Samuelson link between traded TFP and real exchange rates, both in the cross section and time series, but only when we control for non-traded productivity and unit labor costs (reflecting factors that influence labor supply). 


\section{Model Determined Real Exchange Rates under Alternative Exchange Rate Regimes}

We now return to a more detailed quantitative analysis of the properties of the model of Section 2. We solve and simulate a model-produced sample with the same dimensions as the data. This gives us a simulated panel of 9 countries over a 15 year period. In each case, we employ the model to focus on a given country relative to the EU average. Although we only have two countries in the model, we can map it into the empirical observations by treating the Home country as the relevant EU country, and assuming that the Foreign country represents the EU average, in each case. We characterize the time series and cross section properties of real exchange rates and compare the properties of the simulated real exchange rates to those we observe for the empirical sample of Eurozone countries.

\subsection{Model Calibration}

Table 6 lists the calibration values. For the 9 countries used in our complete sample, the average expenditure share on non-traded goods in the PLI data set on consumer goods is $49.9 \%$, so we set $\gamma$, the share of consumption spent on traded goods, equal to 0.5. The share of distribution services in consumption goods has been estimated by Campa and Goldberg (2010) for a number of OECD countries. Their average estimate of the share of distribution services in consumption for the 9 countries in our sample is 41 percent. Hence, we set $\kappa=.6(1-\kappa$ is the share of distribution services in traded goods consumption.). We assume a common value of $\kappa$ for both Home and Foreign goods consumption in both countries. These parameter values together imply that (given other parameter settings) the overall share of non-traded goods in final consumption, including distribution services, is approximately 70 percent.

The elasticity of substitution between Home and Foreign retail goods, $\lambda$, is set at 8, which is the estimate used in Corsetti et al. (2010) ${ }^{16}$. For smaller $\lambda$, real exchange rate volatility increases. But larger values tend to make the Balassa-Samuelson effect

\footnotetext{
${ }^{16}$ Corsetti et. al. (2010) show that this translates into a lower elasticity of substitution between traded wholesale goods, due to the presence of distribution services.
} 
stronger.

Our data gives no information on $\omega$, the weight on Home goods in the composite consumption for traded goods. The presence of non-traded goods in consumption and distribution services already imparts a considerable degree of Home product bias in the overall composition of consumption. Given the presumed relative homogeneity of Eurozone countries in terms of consumption bundles, we therefore set $\omega=0.5$. Also, we set $\alpha$, the elasticity of labor in the production function, equal to one ${ }^{17}$. The parameter $\sigma$, the coefficient of relative risk aversion, is set to equal to 2 , a standard consensus estimate used in DSGE modelling. In addition, the standard value employed for $\psi$, the inverse of the Frisch elasticity of labor supply, is unity, so we set $\psi=1$. The elasticity of substitution between the physical good and the distribution service, $\phi$ is set to 0.25 18.

The elasticity of substitution between traded and non-traded goods, $\theta$, is set to 0.7 , which is a standard estimate from previous literature (e.g. Benigno and Theonissen, 2008). In addition, $\beta$, the discount factor, set equal to 0.99 for quarterly data.

We report results from three different price adjustment assumptions. In Sticky Price Model A, we assume that prices adjust at a rate of 10 percent per quarter, which given the time-dependent pricing mechanism in the Calvo model, implies that the half life of a price is approximately 7 quarters. In Sticky Price model B, prices adjust at a quarterly frequency of 20 percent, implying a half life of price of about 3.5 quarters. Finally, we solve the model with instantaneous price adjustment, so that all nominal variables are fully flexible.

The model has three different kinds of shocks; productivity shocks in each of the two sectors, $a_{i t}, i=H, N$, and shocks to the disutility of labor $\chi_{t}$. Since the key contribution of the model is to facilitate a comparison of the response to the real

\footnotetext{
17 A linear labor technology is a standard assumption in the open macro literature, and as regards the cross section representation of the model, linearity in labor is a long-run equilibrium property of a model with endogenous capital accumulation and an interest rate determined by a constant subjective rate of time preferences.

${ }^{18}$ Corsetti et al. (2010) set this equal to zero. The argument for a low elasticity of substitution is that wholesale goods have to be purchased in fixed supply to obtain a given amount of retail goods, so there is almost no ability to substitute between the distribution services and the wholesale goods themselves in retail production.
} 
exchange rate to productivity and unit labor cost shocks in a parallel way to the empirical estimates, we carefully follow the data in calibrating the shock processes. Appendix B describes in detail our calibration procedure for each of the shocks. Here we give a brief description of this procedure.

Although the model allows for all shocks to occur in both the Home and Foreign country, we set Foreign shocks equal to zero, and calibrate each of the Home country shocks using data relative to the EU set of countries. Since shocks enter the model in relative terms, this is equivalent to treating the EU12 as the Foreign country. Of course, while Foreign shocks are set to zero, the presence of the Foreign country is important because in equilibrium there is a general equilibrium feedback between the Home and Foreign country.

We produce a set of simulated shocks by generating normally distributed random variables for 9 artificial countries that have the same moments as the data. Specifically, the artificial data have the same means, serial correlation, and covariance matrix as the data.

We create moments for traded and non-traded productivity from the same measures of productivity used to construct Tables 2-5. We do not have observations on the labor supply shocks. However, in our model, since we have set the Frisch elasticity of labor supply equal to one and assumed that asset markets are complete, the term that represents the random part of the log of the Home relative to the log of the Foreign disutility of labor, under complete markets, is given by:

$$
\chi_{t}^{*}-\chi_{t}=w_{t}^{*}-n_{t}^{*}-\left(w_{t}-n_{t}\right) .
$$

We can measure the right-hand side of this expression directly from data on wages and employment in each of our 9 countries. This is done by calculating the log of wages per unit of labor effort, and subtracting labor effort from this. Appendix A describes in more detail the data sources and construction for $w$ and $n$.

Our regressions use annual data for 15 years, but we calibrate a period to be one quarter in the model. The length of the period matters particularly when considering the effects of price stickiness. Hence, we create artificial data for 60 quarters. We suppose that the log of quarterly relative TFP (both traded and non-traded) as well 
as labor preference shocks follow first-order autoregressions given by:

$$
a_{t}^{q}-\bar{a}=\rho^{q}\left(a_{t-1}^{q}-\bar{a}\right)+u_{t}^{q}
$$

where $a_{t}$ for each of the 9 countries $\bar{a}$ is directly estimated as in Tables $2-5$. We then aggregate the artificial data into annual data by taking quarterly averages in order to compare the statistics generated by the model to the data. Appendix B describes how we translate the moments of the annual data into quarterly data for the model. In particular, $\rho^{q}$ is computed by taking the quartic root from an $\mathrm{AR}(1)$ estimate on the annual data. The variance covariance matrix over $u_{t}$ is estimated based on the assumption that $u_{t}$ is i.i.d. at quarterly frequency. Theoretically this would make the annual shock an MA(4). In practice, we find that an i.i.d. annual shock adequately captures the dynamics of the annual data.

Table 7 reports the results of the shock estimates in cross section and time series. Table 7 a reports the mean of relative TFP and labor supply shocks for each country. For the productivity measures, this Table reflects the same information as Figures 5-7 above, except averaged over the sample 19 We see considerable variation across the country sample in average sectoral productivities as well as the average relative labor supply term.

Table $7 \mathrm{~b}$ reports the estimates of persistence and volatility of the shocks for each country using the estimates from (15) above. We see that the traded good productivity shock is substantially more volatile and persistent than the non-traded goods shock. This is consistent with other estimates of sectoral productivity shocks in Benigno and Theonissen (2008) and Devereux and Hnatkovska (2013). The labor supply shock is less persistent and much less volatile than either of the sectoral TFP shocks.

Having constructed the shock processes for each of the three shocks, we draw the shocks for the artificial data from a Normal multivariate distributions for the nine Eurozone countries with the three variance-covariance matrices in each case calibrated to the three variance-covariance matrices estimated from the data.

\footnotetext{
${ }^{19}$ Note that the the labor supply shock is relevant for, but separate from the RULC term reported in section 3. The RULC measure represents a combination of all shocks, including the labor supply shock.
} 


\subsection{Simulation Results}

Tables 8 and 9 contain the main set of results from the simulated model under the two different assumptions regarding price adjustment. We report results separately for time series and cross section variation. Differences in the speed of price adjustment features have negligible implications for the cross sectional comparisons, but may be quite important in the time series comparisons.

Table 8a illustrates the standard deviation and persistence properties of real exchange rates in the simulations, and provides the data equivalents for comparison. As in the data, everything is reported at annual frequency. In the model, the time series standard deviation varies between 3.5 and 4 percent across the different price setting assumptions, compared with the empirical estimate of 3.3 percent. The standard deviation is closer to the data under the assumption of sticky prices than with flexible prices. The flexible price model in fact produces real exchange rate volatility that exceeds that of the sample data. 20 The similarity between the simulated real exchange rates and the observed volatility is quite remarkable, since the data driving our shocks comes from an entirely different source than the real exchange rate data. The model produces cross section standard deviations of around 9 percent, substantially higher than the time series standard deviation. This variation reflects the cross-country heterogeneity in mean sectoral TFPs and mean relative labor supply parameters. While the simulated cross-country variation substantially exceeds the average time series variation among the 9 countries in our sample, it still falls somewhat below the 11 percent cross-country standard deviation in the sample data.

The annual frequency persistence in the simulated model is close to that in the data, and particularly close for Sticky Price Model B. We again note that real exchange rate persistence in the model is driven by a combination of persistence in the underlying shocks and the presence of sticky prices, which implies drawn out ad-

\footnotetext{
${ }^{20}$ This represents an interesting contrast with the usual results in the open macro literature, where the combination of sticky prices and floating exchange rates are deemed necessary to produce real exchange rate volatility of an order of magnitude equal to that seen in the data. See for instance, Chari et al. (2002). Here, with flexible prices, nominal price movements lead to real exchange rate adjustment that exceeds that seen in the data, while the assumption of sticky prices has leads to a dampening of real exchange rates, thus more accurately representing the observed volatility.
} 
justment in response to all shocks. Without sticky prices, there is still considerable persistence in the real exchange rate, but it is less than observed in the data.

Table 9 reports the results obtained from running the same regressions of the real exchange rate on relative prices as is done in Table 4, except on the model-simulated data. Recall that these relationships are implied in the model by the decompositions (7) and (8). In the simulated model, the relationships hold identically in time series and cross section. In the data, we find a relationship of the same order of magnitude, although larger in cross section than in time series. For the regressions of $q$ on $q_{n}$, and $q_{T}$ on $q_{n}$, the model produces a regression coefficient above that of the data. This is not surprising since equations (7) and (8) ascribe all variation in real exchange rates to variation in $q_{n}$. In fact, it is quite likely that the cost of non-traded distribution services contains a component that is not accurately measured by observed prices of non-traded goods. If that is the case, then in the results from Table 4 the coefficient on $q_{n}$ in the regression of $q$ on $q_{n}$ (and similarly for the regression of $q_{T}$ on $q_{n}$ ) will be biased downwards due to a classical measurement error problem. This point is established more formally in Appendix B. However, the results of Tables 4 and Table 9 illustrate a clear consistency between the model and the data to the extent that they ascribe a major role for the internal relative price of non-traded goods in driving real exchange rate variation in these Eurozone countries.

Table 9 also shows the results comparable with Table 4c, regressing the model simulated relative price $q$ on $q_{T}$. Again the estimates are the same order of magnitude but still somewhat higher than those in the data.

Tables 10a and 10b present our main set of results of the simulation models. These results are obtained by simulated regressions of the real exchange rate from the model on sectoral TFP and relative unit labor cost (RULC) as implied by the simulated model. Note that in the model, relative unit labor cost is a combination of the three underlying shocks, as implied by (14). Table 10a contains the results for the time series simulations, under the three different assumptions regarding price adjustment, while Table 10b reports the cross-section results.

Table 10a establishes a remarkable coherence between the model and the time series data. As we already established in Table 5, the data provide strong support for 
an amended version of the basic Balassa-Samuelson model for Eurozone real exchange rates. Conditional on relative unit labor costs, a one percent rise in traded goods productivity leads to an 0.18 percent appreciation of the real exchange rate. A one percent rise in non-traded goods productivity leads to a 0.36 percent depreciation of the real exchange rate. On the other hand a one percent increase in relative unit labor costs is associated with a 0.46 percent real exchange rate appreciation.

In all three models, the estimated model coefficients are the same sign and the same order of magnitude as those from the empirical regressions. Both Sticky Price Models A and B in particular lead to simulated regression coefficients extremely close to those in the data; in the model $\mathrm{A}$ a one percent rise in traded goods productivity leads to a 0.19 percent appreciation, a one percent rise in non-traded good productivity leads to a 0.32 percent real exchange rate depreciation, and a one percent rise in the relative unit labor cost leads to a 0.34 percent real exchange rate appreciation.

These results establish that a very basic open economy macro model amended to allow for labor supply shocks can provide a highly accurate representation of the time series behaviour or Eurozone real exchange rates. Morever, both model and data offer strong support for the traditional Balassa-Samuelson approach to real exchange rates, amended for the presence of labor supply shocks.

What role do sticky prices play in the explanation? As we saw in Table 8, sticky prices help to enhance the persistence properties of the real exchange rate, bringing the model closer to the data. But from Table 10a, we see that sticky prices play an important role in tempering the response of the model to the different shocks. In general, flexible price DSGE models enhance the response of real variables to 'supply shocks', and lessen the response to 'demand' shocks. We might think of both the labor supply shock and the traded goods productivity shock as more akin to supply shocks, and the non-traded goods productivity shock as more of a demand shock. ${ }^{21}$ With flexible prices, the simulated regressions produced an exaggerated real exchange rate response to traded goods productivity shocks and to relative unit labor cost costs, while limiting the response to the non-traded goods productivity shock. Under sticky

\footnotetext{
${ }^{21}$ Shocks to traded goods productivity can be more easily smoothed out through capital markets, while shocks to non-traded goods productivity must feed fully into domestic consumption.
} 
prices, the impact of the supply shocks are reduced and the response to the demand shock is enhanced. Hence, the sticky price model gives a very accurate representation of the time series response of the real exchange rate to all shocks.

Table $10 \mathrm{~b}$ reports the cross section results. Here, the difference in price adjustment frequencies across the three models has much less importance. But all different specifications lead to regression coefficients of the right sign, and in the case of the non-traded good productivity shock, and the relative unit labor cost shock, the simulation estimates are extremely close to those in the data. In particular, the data indicates that a country with a non-traded goods productivity one percent above the average will have a real exchange rate about 0.3 percent below the average. The simulated model reproduces this almost exactly. Likewise, a country with relative unit labor costs one percent above average will have a real exchange rate 0.4 percent above the average. Again, the simulated regression coefficient matches this very closely. With respect to the traded good productivity shock, the simulated model coefficient produces the right sign, but the implied real exchange rate response is a bit under half that found in the data.

Overall, these estimates are remarkable for the fact that they indicate that the relationship between real exchange rates and sectoral productivity can be well accounted for by a standard two-sector New Keynesian model, in a manner which closely resembles the empirical relationship estimated from Eurozone data. Moreover, both model and empirical estimates offer a new lease of life for an amended version of the Balassa-Samuelson model of real exchange rate determination.

\section{Conclusions}

We have seen that the real exchange rates in the Eurozone closely reflect differences in the relative prices of non-traded to traded goods across countries, and in turn differences in the relative productivity levels in the traded versus non-traded sectors, as well as variations in unit labor costs. Under the assumption of empirically relevant degrees of price stickiness, the actual pattern of prices and real exchange rates closely mirrors the pattern produced in the simulations from our model. 
It may seem surprising that even when nominal prices are sticky, real exchange rate behavior accords well with the Balassa-Samuelson theory, which has been until now primarily considered a theory of long-run equilibrium real exchange rates. There are perhaps three reasons why the theory fits well for the Eurozone data. First, the initial accession rates in the Eurozone were set in effect to minimize deviations in traded goods prices across countries. So in 1999, the real exchange rates within the Eurozone were effectively initialized at levels that reflect the differences in their non-traded goods prices and differences in distribution costs.

Second, relative productivity shocks over time within the Eurozone simply are not that big. That is, the equilibrium or flexible-price real exchange rate within the Eurozone does not change very much over time. If the initial real exchange rates are near the equilibrium level then even with no further adjustment of the actual real exchange rates, they will not differ too much from the equilibrium rates simply because the equilibrium rates do not stray very far from the initial levels. In a sense, this observation merely restates the point made by Rogoff (1996) in the context of the puzzling behavior of real exchange rates under floating nominal rates. He said that real exchange rate volatility we observe among floating rate countries is impossible to explain if only real productivity shocks drove real exchange rates - that monetary and financial factors must play a role: "existing models based on real shocks cannot account for short-term exchange rate volatility" (p. 648). Equilibrium real exchange rates are not very volatile, and since the currency union eliminates relative monetary shocks, the real exchange rate under a currency union is also not very volatile.

Third, nominal prices do adjust over time, so even in a currency union there is real exchange rate adjustment. It is worth emphasizing that the choice of exchange rate regime only matters for real exchange rate adjustment because nominal prices are sticky. The speed of adjustment of real exchange rates is limited only by the speed of adjustment of nominal prices. While the point is obvious, it still is often overlooked. For example, it is frequently argued that the Eurozone is a poor candidate for a currency union because labor is not very mobile within the Eurozone. But the degree of labor mobility can only matter for the choice of exchange-rate regime if mobility can substitute for nominal wage and price adjustment. That is, labor immobility 
may well mean that adjustment to real shocks in the Eurozone is slower than in the U.S. where labor is more mobile. However, this refers to an equilibrium adjustment - the problem would exist in the Eurozone even if prices and wages were flexible. Put another way, labor mobility can substitute for nominal exchange rate adjustment only if labor moves at higher frequencies than prices and wages adjust.

Of course, there are other sources of shocks that may affect real exchange rates in the Eurozone. For instance, shocks to fiscal spending can affect relative non-traded goods prices and real exchange rates. But our data sample does not include the period of recent major fiscal adjustments in Europe. Berka and Devereux (2013) found little evidence for an important role for government spending to GDP as a determinant of real exchange rate in a sample that did not include the European post-2009 crisis.

Finally, because our empirical analysis does not include the period of the sovereign debt crisis in Europe, our model does not consider real exchange rate adjustment in crises situations. It might well be the case that under a crisis, the real exchange rate adjustment that occurs under floating rates is more desirable than what occurs in a currency union. Schmitt-Grohe and Uribe's (2013) show that the combination of downward nominal wage rigidity and credit constraints could be very important in the inhibiting efficient real exchange rates under fixed exchange rates during a crisis. 
6 Tables 
Table 1. PLI basic headings, Household expenditures

\begin{tabular}{|c|c|c|c|}
\hline $\mathrm{T}$ & Rice & $\mathrm{T}$ & Major tools and equipment \\
\hline $\mathrm{T}$ & Other cereals, flour and other cereal products & $\mathrm{T}$ & Small tools and miscellaneous accessories \\
\hline $\mathrm{T}$ & Bread & $\mathrm{T}$ & Non-durable household goods \\
\hline $\mathrm{T}$ & Other bakery products & NT & Domestic services \\
\hline $\mathrm{T}$ & Pasta products & NT & Household services \\
\hline $\mathrm{T}$ & Beef and Veal & $\mathrm{T}$ & Pharmaceutical products \\
\hline $\mathrm{T}$ & Pork & $\mathrm{T}$ & Other medical products \\
\hline $\mathrm{T}$ & Lamb, mutton and goat & $\mathrm{T}$ & Therapeutical appliances and equipment \\
\hline $\mathrm{T}$ & Poultry & NT & Medical Services \\
\hline $\mathrm{T}$ & Other meats and edible offal & NT & Services of dentists \\
\hline $\mathrm{T}$ & Delicatessen and other meat preparations & NT & Paramedical services \\
\hline $\mathrm{T}$ & Fresh, chilled or frozen fish and seafood & NT & Hospital services \\
\hline $\mathrm{T}$ & Preserved or processed fish and seafood & $\mathrm{T}$ & Motor cars with diesel engine \\
\hline $\mathrm{T}$ & Fresh milk & $\mathrm{T}$ & Motor cars with petrol engine of cubic capacity of less than $1200 \mathrm{cc}$ \\
\hline $\mathrm{T}$ & Preserved milk and other milk products & $\mathrm{T}$ & Motor cars with petrol engine of cubic capacity of $1200 \mathrm{cc}$ to $1699 \mathrm{cc}$ \\
\hline $\mathrm{T}$ & Cheese & $\mathrm{T}$ & Motor cars with petrol engine of cubic capacity of $1700 \mathrm{cc}$ to $2999 \mathrm{cc}$ \\
\hline $\mathrm{T}$ & Eggs and egg-based products & $\mathrm{T}$ & Motor cars with petrol engine of cubic capacity of $3000 \mathrm{cc}$ and over \\
\hline $\mathrm{T}$ & Butter & $\mathrm{T}$ & 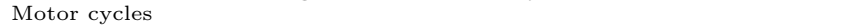 \\
\hline $\mathrm{T}$ & Margarine & $\mathrm{T}$ & Bicycles \\
\hline $\mathrm{T}$ & Other edible oils and fats & $\mathrm{T}$ & Animal drawn vehicles \\
\hline $\mathrm{T}$ & Fresh or chilled fruit & $\mathrm{T}$ & Spare parts and accessories for personal transport equipment \\
\hline $\mathrm{T}$ & Frozen, preserved or processed fruit & $\mathrm{T}$ & Fuels and lubricants for personal transport equipment \\
\hline $\mathrm{T}$ & Fresh or chilled vegetables other than potatoes & NT & Maintenance and repair of personal transport equipment \\
\hline $\mathrm{T}$ & Fresh or chilled potatoes & NT & Other services in respect of personal transport equipment \\
\hline $\mathrm{T}$ & Frozen, preserved or processed vegetables & NT & Passenger transport by railway \\
\hline $\mathrm{T}$ & Sugar & NT & Passenger transport by road \\
\hline $\mathrm{T}$ & Jams, marmalades and honey & NT & Passenger transport by air \\
\hline $\mathrm{T}$ & Confectionery, chocolate and other cocoa preps & NT & Passenger transport by sea and inland waterway \\
\hline $\mathrm{T}$ & Edible ice, ice cream and sorbet & NT & Combined passenger transport \\
\hline $\mathrm{T}$ & Coffee, tea and cocoa & NT & Other purchased transport services \\
\hline $\mathrm{T}$ & Mineral waters & NT & Postal services \\
\hline $\mathrm{T}$ & Soft drinks and concentrates & $\mathrm{T}$ & Telephone and telefax equipment \\
\hline $\mathrm{T}$ & Fruit and vegetable juices & NT & Telephone and telefax services \\
\hline $\mathrm{T}$ & Spirits & $\mathrm{T}$ & Equipment for reception, recording and reproduction of sound and pictures \\
\hline $\mathrm{T}$ & Wine & $\mathrm{T}$ & Photographic and cinematographic equipment and optical instruments \\
\hline $\mathrm{T}$ & Beer & $\mathrm{T}$ & Information processing equipment \\
\hline $\mathrm{T}$ & Tobacco & $\mathrm{T}$ & Pre-recorded recording media \\
\hline $\mathrm{T}$ & Narcotics & $\mathrm{T}$ & Unrecorded recording media \\
\hline $\mathrm{T}$ & Other clothing and clothing accessories & NT & Repair of audio-visual, photographic and information processing equipment \\
\hline $\mathrm{T}$ & Clothing materials & $\mathrm{T}$ & Major durables for outdoor recreation \\
\hline $\mathrm{T}$ & Men's clothing & $\mathrm{T}$ & Musical instruments and major durables for indoor recreation \\
\hline $\mathrm{T}$ & Women's clothing & NT & Maintenance and repair of other major durables for recreation and culture \\
\hline $\mathrm{T}$ & Childrens and infants clothing & $\mathrm{T}$ & Games, toys and hobbies \\
\hline $\mathrm{T}$ & Other clothing and clothing accessories & $\mathrm{T}$ & Equipment for sport, camping and open-air recreation \\
\hline NT & Cleaning, repair and hire of clothing & $\mathrm{T}$ & Gardens, plants and flowers \\
\hline $\mathrm{T}$ & Men's footwear & $\mathrm{T}$ & Pets and related products \\
\hline $\mathrm{T}$ & Women's footwear & $\mathrm{T}$ & Veterinary and other services for pets \\
\hline $\mathrm{T}$ & Children's and infant's footwear & NT & Recreational and sporting services \\
\hline NT & Repair and hire of footwear & NT & Photographic services \\
\hline NT & Actual rentals for housing & NT & Other cultural services \\
\hline NT & Imputed rentals for housing & $\mathrm{T}$ & Games of chance \\
\hline $\mathrm{T}$ & Materials for maintenance and repair of dwelling & $\mathrm{T}$ & Books \\
\hline NT & Services for maintenance and repair of dwelling & $\mathrm{T}$ & Newspapers and periodicals \\
\hline NT & Water supply & $\mathrm{T}$ & Miscellaneous printed matter, stationery and drawing materials \\
\hline NT & Miscellaneous services relating to the dwelling & $\mathrm{T}$ & Package holidays \\
\hline $\mathrm{T}$ & Electricity & NT & Pre-primary and primary education \\
\hline $\mathrm{T}$ & Gas & NT & Secondary education \\
\hline $\mathrm{T}$ & Liquid fuels & NT & Post-secondary education \\
\hline $\mathrm{T}$ & Solid fuels & NT & Tertiary education \\
\hline $\mathrm{T}$ & Heat energy & NT & Education not definable by level \\
\hline $\mathrm{T}$ & Kitchen furniture & NT & Restaurant services whatever the type of establishment \\
\hline $\mathrm{T}$ & Bedroom furniture & NT & Pubs, bars, cafs, tea rooms and the like \\
\hline $\mathrm{T}$ & Living-room and dining-room furniture & NT & Canteens \\
\hline $\mathrm{T}$ & Other furniture and furnishings & NT & Accommodation services \\
\hline $\mathrm{T}$ & Carpets and other floor coverings & NT & Hairdressing salons and personal grooming establishments \\
\hline NT & Repair of furniture, furnishings and floors & $\mathrm{T}$ & Electric appliances for personal care \\
\hline $\mathrm{T}$ & Household textiles & $\mathrm{T}$ & Other appliances, articles and products for personal care \\
\hline $\mathrm{T}$ & Major household appliances electric or not & NT & Prostitution \\
\hline $\mathrm{T}$ & Small electric household appliances & $\mathrm{T}$ & Jewellery, clocks and watches \\
\hline NT & Repair of household appliances & $\mathrm{T}$ & Other personal effects \\
\hline \multirow[t]{4}{*}{$\mathrm{T}$} & Glassware, tableware and household utensils & NT & Social protection \\
\hline & & NT & Insurance \\
\hline & & NT & Other financial services n.e.c. \\
\hline & & NT & Other services n.e.c. \\
\hline
\end{tabular}




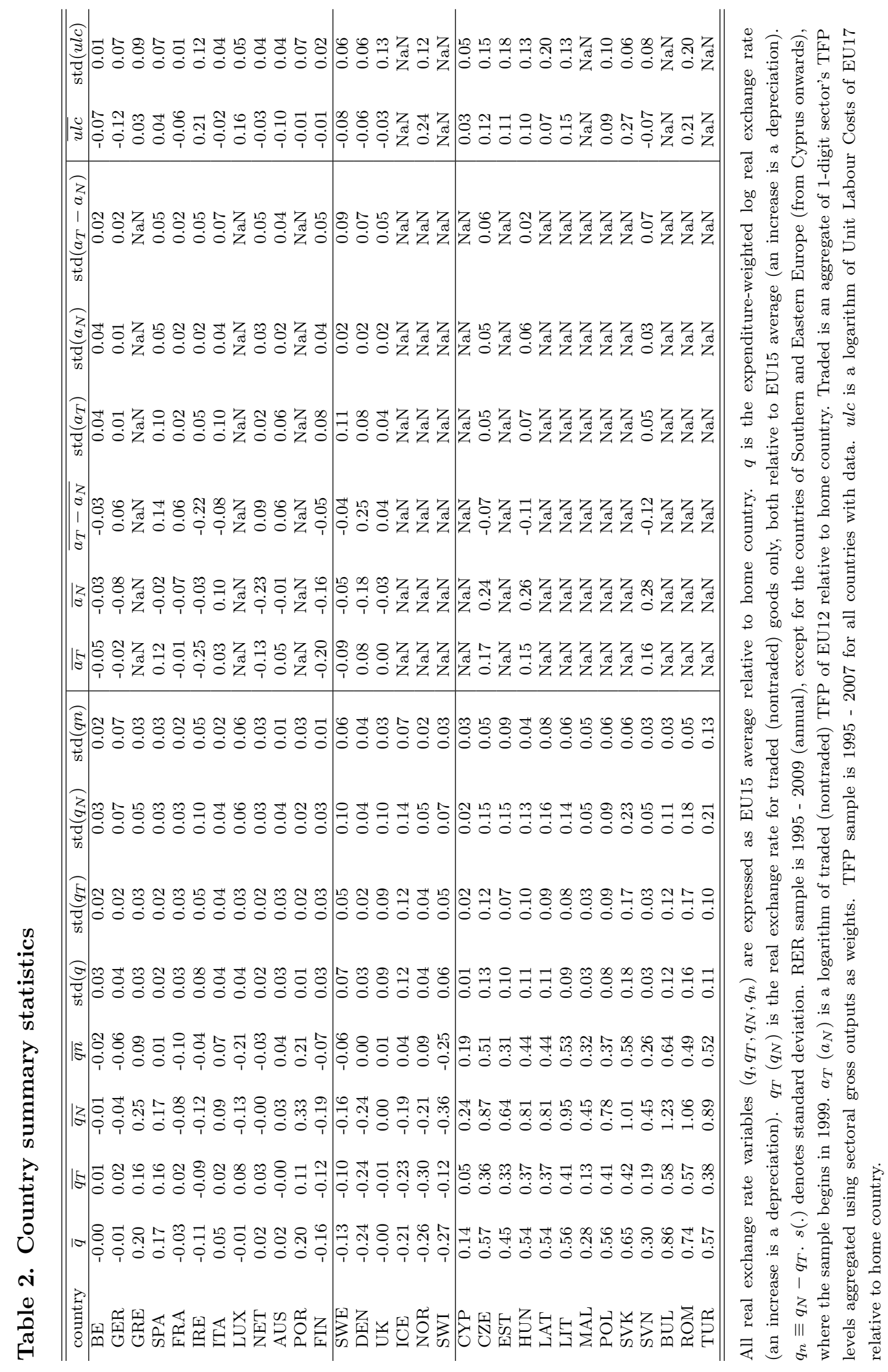


Table 3. Standard deviations

\begin{tabular}{lcccc|cccc}
\multicolumn{5}{c}{ mean $\left(\operatorname{std}_{i}().\right)$} & \multicolumn{4}{c}{$\operatorname{std}\left(\operatorname{mean}_{i}().\right)$} \\
variable & All & EZ & Float & East & All & EZ & Float & East \\
\hline$q$ & 0.067 & 0.033 & 0.070 & 0.098 & 0.328 & 0.113 & 0.103 & 0.193 \\
$q_{T}$ & 0.061 & 0.028 & 0.060 & 0.091 & 0.238 & 0.087 & 0.109 & 0.154 \\
$q_{N}$ & 0.088 & 0.044 & 0.084 & 0.129 & 0.471 & 0.158 & 0.120 & 0.275 \\
$q_{n}$ & 0.045 & 0.032 & 0.043 & 0.059 & 0.253 & 0.107 & 0.119 & 0.133 \\
\hline$a_{T}$ & 0.059 & 0.055 & 0.075 & 0.055 & 0.129 & 0.121 & 0.083 & 0.014 \\
$a_{N}$ & 0.031 & 0.031 & 0.019 & 0.045 & 0.155 & 0.093 & 0.078 & 0.017 \\
$a_{T}-a_{N}$ & 0.049 & 0.040 & 0.070 & 0.052 & 0.119 & 0.111 & 0.151 & 0.027 \\
\hline$u l c$ & 0.088 & 0.053 & 0.092 & 0.128 & 0.113 & 0.097 & 0.151 & 0.093 \\
\hline
\end{tabular}

All real exchange rate variables are expressed relative to EU15 average (=0 each year). $q$ is the expenditure-weighted log real exchange rate (increase is a depreciation). $q_{T}$ $\left(q_{N}\right)$ is the same real exchange rate but for traded (nontraded) goods only, both relative to EU15 average (increase is a depreciation) $q_{n} \equiv q_{N}-q_{T}$. RER sample is $1995-2009$, except for the countries of Southern and Eastern Europe, where the sample begins in 1999. $a_{T}\left(a_{N}\right)$ is a logarithm of traded (nontraded) TFP relative to EU12. Traded constitutes an aggregate of 1-digit sector's TFP levels aggregated using sectoral gross outputs as weights. TFP sample is $1995-2007$ for all countries with data (see previous Table). ulc is a logarithm of Unit Labour Costs of EU17 relative to home country (the sample period is 1995 - 2009, except for Southern and East European countries).

The left panel reports average time series standard deviation $\left(\operatorname{std}_{i}(\right.$.$) , where i$ indexes countries). The right panel reports the standard deviation of average real exchange rates $\left(\operatorname{mean}_{i}(\right.$.$) , where i$ indexes countries). 


\section{Table 4. Price regressions}

Table 4a: Regression of $q$ on the $q_{n}$

\begin{tabular}{rrrrr}
\hline & 1 & 2 & 3 & 4 \\
& Pool & $\mathrm{FE}$ & $\mathrm{RE}$ & $\mathrm{XS}$ \\
\hline $\mathbf{q}_{\mathbf{n}}$ & $\mathbf{0 . 7 0}^{* * *}$ & $\mathbf{0 . 6 0}^{* * *}$ & $\mathbf{0 . 6 1}^{* * *}$ & $\mathbf{0 . 7 1}^{* *}$ \\
& $(0.058)$ & $(0.076)$ & $(0.07)$ & $(0.247)$ \\
\hline $\bar{R}^{2}$ & 0.44 & 0.93 & 0.36 & 0.40 \\
$\mathrm{~N}$ & 180 & 180 & 180 & 12 \\
$\mathrm{HT}$ & - & - & not reject & - \\
\hline \hline
\end{tabular}

Table 4b new: Regression of $q_{T}$ on $q_{n}$

\begin{tabular}{rrrrr}
\hline & 5 & 6 & 7 & 8 \\
& Pool & FE & RE & XS \\
\hline qn & $\mathbf{0 . 2 6}^{* * *}$ & 0.11 & $\mathbf{0 . 1 2}^{*}$ & $\mathbf{0 . 8 9}^{* * *}$ \\
& $(0.057)$ & $(0.076)$ & $(0.07)$ & $(0.12)$ \\
\hline $\bar{R}^{2}$ & 0.10 & 0.89 & 0.02 & 0.70 \\
$\mathrm{~N}$ & 180 & 180 & 180 & 12 \\
$\mathrm{HT}$ & - & - & not reject & - \\
\hline \hline
\end{tabular}

Table 4c: Regression of the $q$ on $q_{T}$

\begin{tabular}{rrrrr}
\hline & 9 & 10 & 11 & 12 \\
& Pool & $\mathrm{FE}$ & $\mathrm{RE}$ & $\mathrm{XS}$ \\
\hline $\mathbf{q}_{\mathrm{T}}$ & $\mathbf{1 . 1 9}^{* * *}$ & $\mathbf{1 . 0 8}^{* * *}$ & $\mathbf{1 . 0 9}^{* * *}$ & $\mathbf{1 . 2 0}^{* * *}$ \\
& $(0.038)$ & $(0.053)$ & $(0.048)$ & $(0.11)$ \\
\hline $\bar{R}^{2}$ & 0.84 & 0.98 & 0.77 & 0.83 \\
$\mathrm{~N}$ & 180 & 180 & 180 & 12 \\
$\mathrm{HT}$ & - & - & not reject & - \\
\hline \hline
\end{tabular}

Real exchange rate $q$ is expressed as the logarithm of expenditure-weighted real exchange rate EU15 average relative to country $i$ (an increase is a depreciation). $q_{T}$ is the logarithm of the expenditure-weighted real exchange rate of tradables in EU15 on average, relative to country $i$ (an increase is a depreciation). $q_{n}$ is the $\log$ of the relative price of nontraded to traded goods (all expenditure-weighted) in EU15 on average, relative to country $i\left(q_{n} \equiv q_{N}-q_{T}\right)$. The sample period for all variables is 1995-2009. Pool is a pooled regression with all countries and years sharing the same estimate of a constant and a slope. $F E$ is a fixed-effects panel regression with countries as cross sections. $R E$ is a random effects regression with countries as cross sections. $X S$ is a cross-sectional regression which uses time-average values of variables in each country. All standard errors are computed using a panel adjustment robust to serial correlation (except for $X S$, where Newey-West adjustment is used). Standard errors are in parentheses. The estimate of the constant is not reported. A * denotes a $10 \%,{ }^{* *} 5 \%$ and ${ }^{* * *} 1 \%$ significance. Eurozone countries in our sample are: Austria, Belgium, Germany, Greece, France, Finland, Italy, Ireland, Luxembourg, the Netherlands, Portugal, and Spain. Rejection of the null at 5\% in Hausman test (HT) implies no difference between $\mathrm{FE}$ and $\mathrm{RE}$, viewed as a preference for $\mathrm{FE}$. 


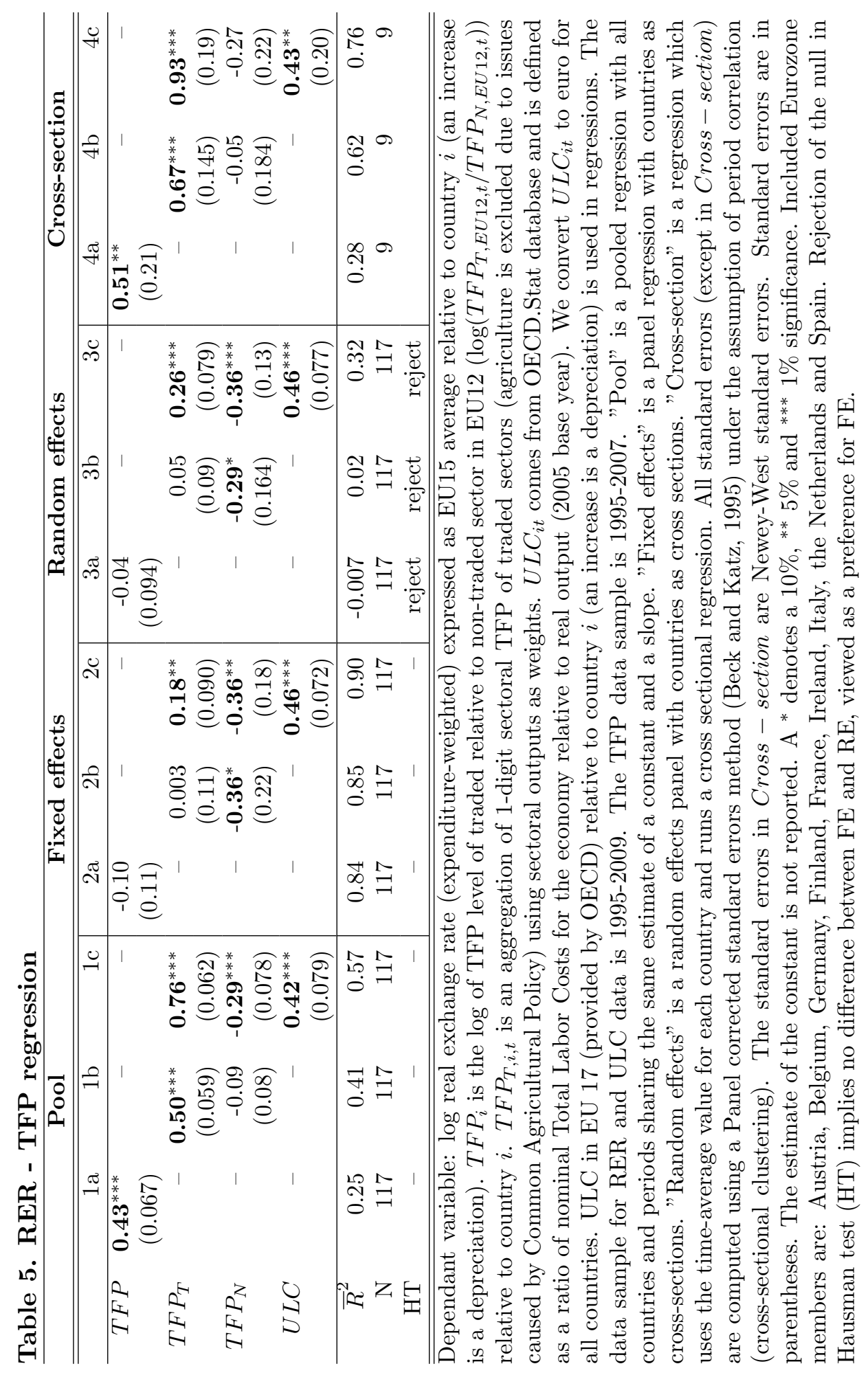




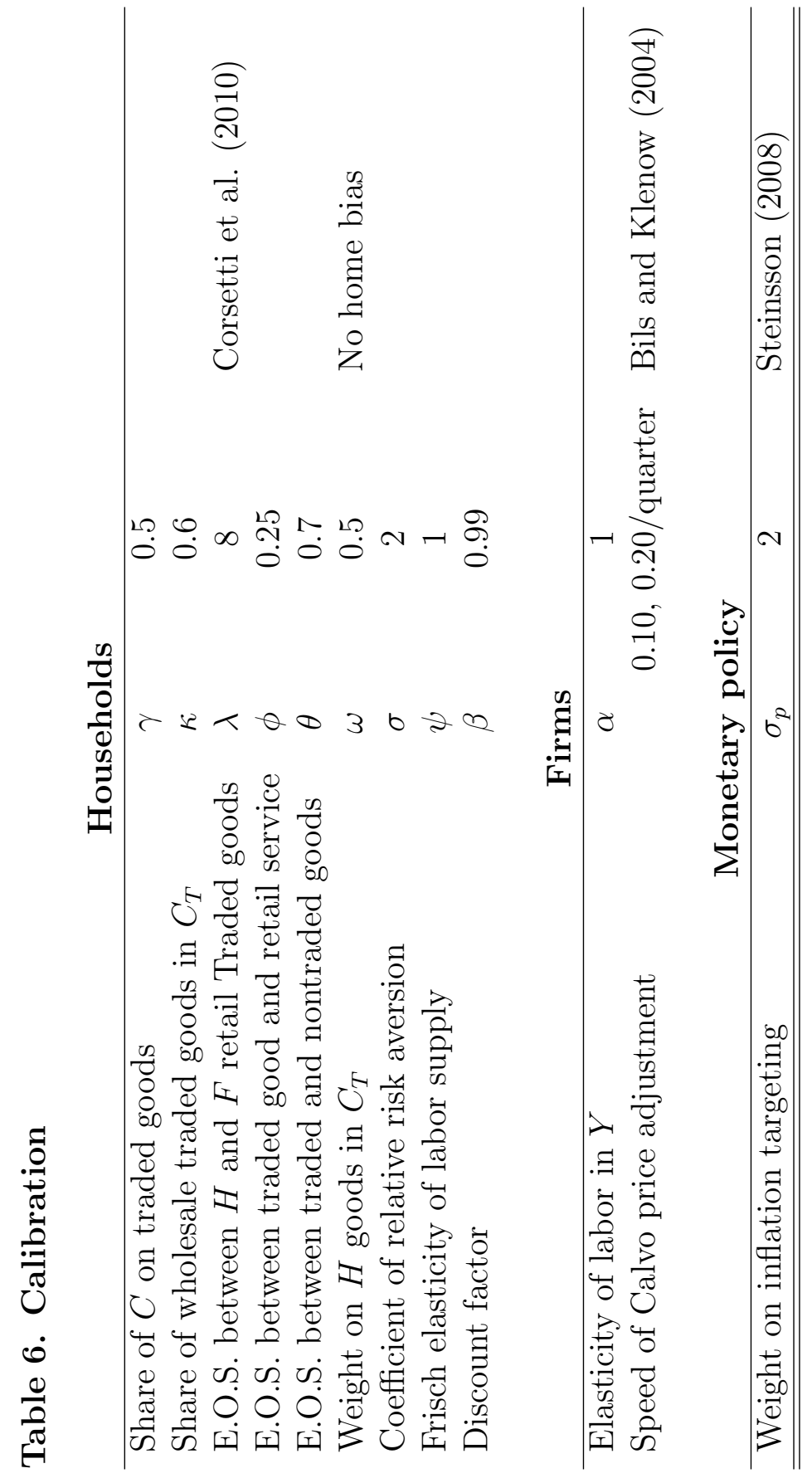


Table 7a. Cross-sectional properties of relative TFP and Labor Supply shocks

\begin{tabular}{l|rrr}
\hline & \multicolumn{3}{|c}{ mean values } \\
& $\bar{a}_{T}$ & $\bar{a}_{N}$ & $\bar{\chi}$ \\
\hline BEL & 0.054 & 0.028 & 0.218 \\
GER & 0.019 & 0.078 & 0.026 \\
SPA & -0.119 & 0.025 & -0.308 \\
FRA & 0.009 & 0.069 & 0.093 \\
IRE & 0.251 & 0.028 & 0.133 \\
ITA & -0.028 & -0.103 & -0.301 \\
NET & 0.131 & 0.225 & 0.057 \\
AUS & -0.049 & 0.014 & -0.002 \\
FIN & 0.202 & 0.156 & 0.027 \\
\hline AVG & 0.052 & 0.058 & -0.006 \\
\hline
\end{tabular}

Table 7a reports, for each country, the sample average level of the of TFP and Labor supply shock as described by Appendix A.1. and A.7., respectively. The last line ("AVG") reports the average value across 9 countries.

Table $7 \mathrm{~b}$. Time-series properties of relative TFP and Labor Supply shocks

\begin{tabular}{l|ccc|ccc}
\hline & \multicolumn{2}{|c}{$\mathrm{AR}(1)$ coefficients } & \multicolumn{3}{c}{ standard deviations } \\
& $\rho_{a_{T}}$ & $\rho_{a_{N}}$ & $\rho_{\chi}$ & $\sigma_{a_{T}}$ & $\sigma_{a_{N}}$ & $\sigma_{\chi}$ \\
\hline BEL & 0.99 & 0.95 & 0.82 & 1.11 & 0.82 & 0.17 \\
GER & 0.94 & 0.90 & 0.93 & 1.75 & 0.62 & 0.12 \\
SPA & 0.99 & 0.97 & 0.95 & 1.65 & 0.86 & 0.16 \\
FRA & 0.89 & 0.91 & 0.92 & 1.24 & 1.18 & 0.11 \\
IRE & 0.89 & 0.69 & 0.99 & 3.69 & 1.79 & 0.29 \\
ITA & 0.99 & 0.98 & 0.73 & 0.91 & 1.14 & 0.14 \\
NET & 0.92 & 0.99 & 0.90 & 1.43 & 1.03 & 0.23 \\
AUS & 0.98 & 0.96 & 0.86 & 2.02 & 0.95 & 0.13 \\
FIN & 0.99 & 0.97 & 0.89 & 1.34 & 1.24 & 0.19 \\
\hline AVG & 0.95 & 0.92 & 0.89 & 1.68 & 1.07 & 0.17
\end{tabular}

Table $7 \mathrm{~b}$ reports, for each country, the first-order autocorrelation coefficient, and the standard deviation of the residual series, for TFP and Labor supply shocks, as described by Appendix A.1. and A.7., respectively. The last line ("AVG") reports the average value across 9 countries. 
Table 8. Properties of model Real Exchange Rates

\begin{tabular}{cccc|c}
\hline & Sticky price A & Sticky price B & Flexible price & Data \\
\hline \hline & 1 & 2 & 4 & 5 \\
\hline STD & 0.035 & 0.037 & 0.042 & 0.033 \\
(Time Series) & $(0.029,0.041)$ & $(0.032,0.044)$ & $(0.036,0.048)$ & \\
\hline STD & 0.085 & 0.087 & 0.088 & 0.113 \\
(Cross Section) & $(0.058,0.124)$ & $(0.061,0.126)$ & $(0.059,0.129)$ & \\
\hline Serial & 0.724 & 0.685 & 0.604 & 0.670 \\
Correlation & $(0.642,0.798)$ & $(0.597,0.777)$ & $(0.506,0.690)$ & \\
\hline
\end{tabular}

$\overline{\text { Results in the "Data" column repeat those from Table 5. Results in the other columns are based }}$ on regressions with simulated data (500 simulations of the DGP, as described in Appendix B, with $\kappa=0.6$ and $\gamma=0.5)$. As in our data, panels of synthetic data are generated for 15-year (60quarter) periods. $10 \%$ standard errors are reported in the parentheses. The calibration in column "Sticky price A" assumes a $10 \%$ price adjustment per quarter. "Sticky price B" assumes a $20 \%$ price adjustment per quarter.

TABLE 9. Model price regressions

Table 9a: Time Series Regressions

\begin{tabular}{rcccc}
\hline & Sticky price A & Sticky price B & Flexible price & Data \\
\hline \hline Regression of & 1 & 2 & 3 & 4 \\
$q$ on $q_{n}$ & $(1.149,1.189)$ & $(1.150,1.192)$ & $(1.153,1.192)$ & \\
\hline Regression of & 0.665 & 0.665 & 0.666 & 0.11 \\
$q_{T}$ on $q_{n}$ & $(0.647,0.681)$ & $(0.648,0.681)$ & $(0.649,0.682)$ & \\
\hline Regression of & 1.752 & 1.757 & 1.756 & 1.08 \\
$q$ on $q_{T}$ & $(1.722,1.794)$ & $(1.720,1.790)$ & $(1.722,1.789)$ & \\
\hline \hline
\end{tabular}

Table 9b: Cross Section Regressions

\begin{tabular}{rcccc}
\hline & Sticky price A & Sticky price B & Flexible price & Data \\
\hline \hline Regression of & 5 & 6 & 7 & 8 \\
$q$ on $q_{n}$ & $(1.125,1.203)$ & $(1.127,1.200)$ & $(1.127,1.201)$ & \\
\hline Regression of & 0.660 & 0.662 & 0.662 & 0.89 \\
$q_{T}$ on $q_{n}$ & $(0.629,0.692)$ & $(0.632,0.689)$ & $(0.633,0.689)$ & \\
\hline Regression of & 1.757 & 1.757 & 1.757 & 1.20 \\
$q$ on $q_{T}$ & $(1.722,1.794)$ & $(1.720,1.790)$ & $(1.732,1.785)$ & \\
\hline \hline
\end{tabular}

Results in the "Data" column repeat those from Table 5. Results in the other columns are based on regressions with simulated data (500 simulations of the DGP, as described in Appendix B, with $\kappa=0.6$ and $\gamma=0.5$ ). As in our data, panels of synthetic data are generated for 15-year (60-quarter) periods. $10 \%$ standard errors are reported in the parentheses. The calibration in column "Sticky price A" assumes a 10\% price adjustment per quarter. "Sticky price B" assumes a $20 \%$ price adjustment per quarter. 
Table 10a. Time Series Regression Results

\begin{tabular}{cccc|c}
\hline & Sticky price A & Sticky price B & Flexible price & Data \\
\hline \hline Traded TFP & 1 & 2 & 4 & 5 \\
& 0.191 & 0.206 & 0.216 & 0.18 \\
& $(0.094,0.276)$ & $(0.132,0.276)$ & $(0.194,0.241)$ & \\
\hline Nontraded TFP & -0.322 & -0.292 & -0.223 & -0.36 \\
& $(-0.444,-0.197)$ & $(-0.393,-0.171)$ & $(-0.249,-0.204)$ & \\
\hline ULC & 0.341 & 0.437 & 0.698 & 0.46 \\
& $(0.301,0.444)$ & $(0.401,0.486)$ & $(0.682,0.710)$ & \\
\hline \hline
\end{tabular}

Table 10b. Cross Section Regression Results

\begin{tabular}{cccc|c}
\hline & Sticky price A & Sticky price B & Flexible price & Data \\
\hline \hline Traded TFP & 6 & 7 & 9 & 10 \\
& 0.351 & 0.350 & 0.354 & 0.93 \\
Nontraded TFP & $(0.252,0.448)$ & $(0.260,0.455)$ & $(0.245,0.481)$ & \\
& -0.271 & -0.263 & -0.259 & -0.27 \\
\hline ULC & $(-0.371,-0.149)$ & $(-0.377,-0.136)$ & $(-0.380,-0.129)$ & \\
& 0.437 & 0.457 & 0.471 & 0.43 \\
\hline \hline
\end{tabular}

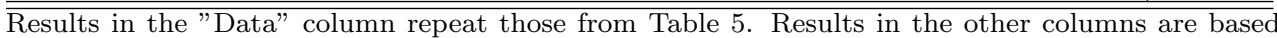
on regressions with simulated data (500 simulations of the DGP, as described in Appendix B, with $\kappa=0.6$ and $\gamma=0.5)$. As in our data, panels of synthetic data are generated for 15-year (60quarter) periods. $10 \%$ standard errors are reported in the parentheses. The calibration in column "Sticky price A" assumes a 10\% price adjustment per quarter. "Sticky price B" assumes a $20 \%$ price adjustment per quarter. 


\section{$\begin{array}{ll}7 & \text { Figures }\end{array}$}
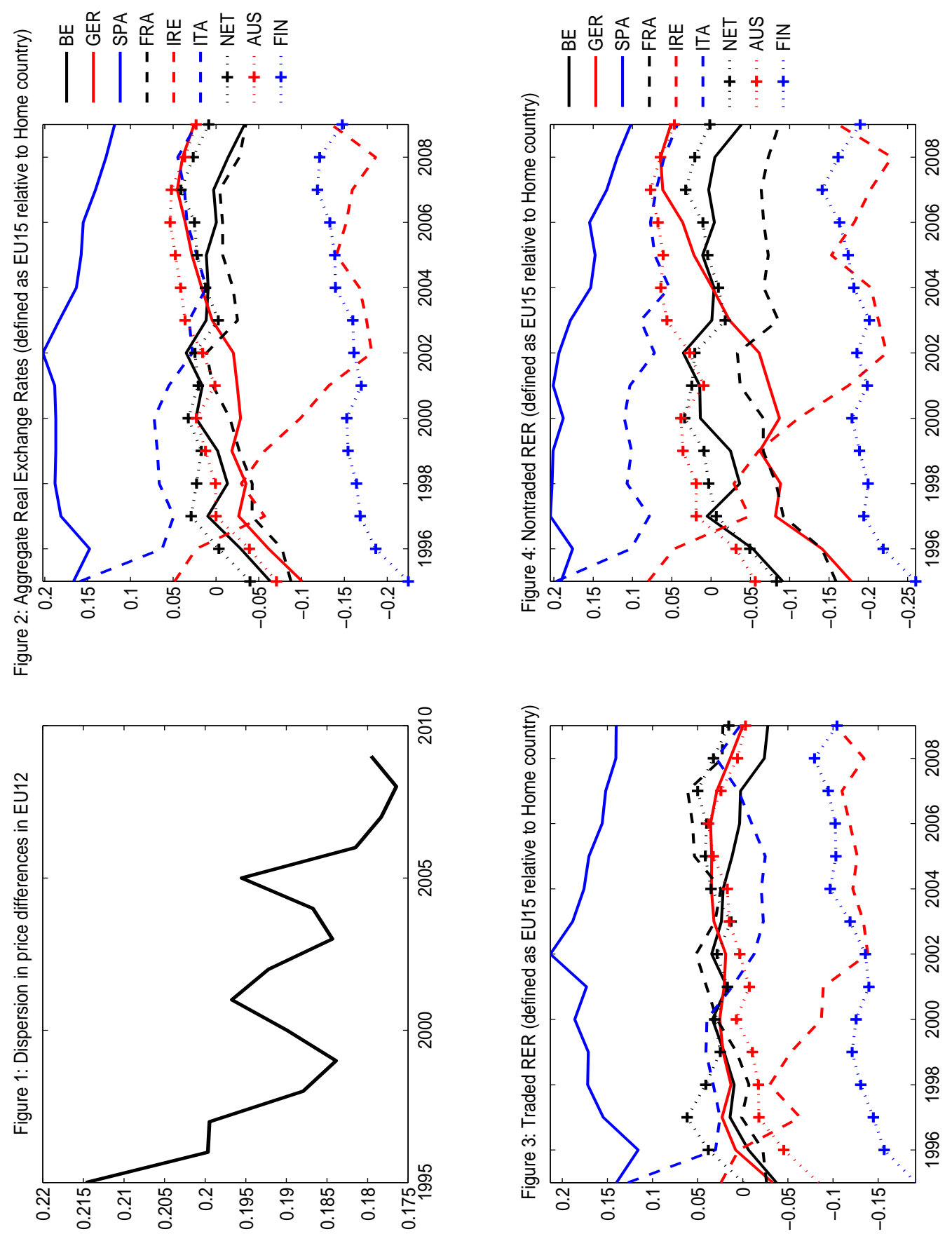

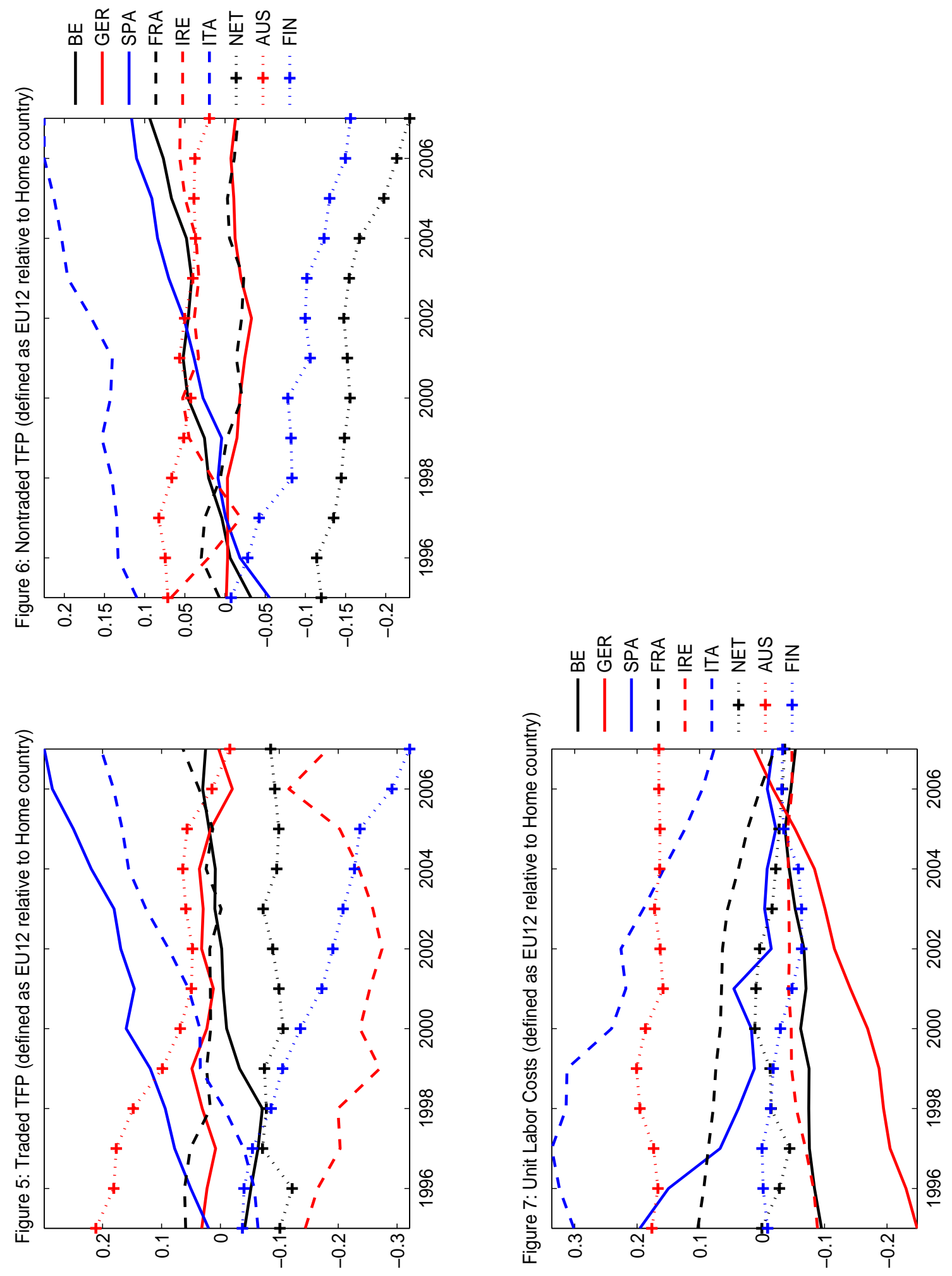


\section{A Data Appendix}

\section{A.1 Construction of the panel of sectoral TFP levels across Europe}

This section documents the construction of the TFP level panel dataset at sectoral level. The reason for the construction of this dataset to provide the perfect match to the level data of real exchange rates across Europe. To construct the dataset, we construct a concordance between the sectors included in the Groningen Growth and Development Center's (GGDC thereafter) 1997 TFP level database, and the sectors included in the KLEMS time-series database. These two databases are meant to be used in conjunction, as outlined in Inklaar and Timmer (2008). Then, the cross-sectional TFP database and the time-series TFP database are linked using the constructed concordance to obtain annual sectoral panel TFP level data.

Table A1 lists the sectors included in the TFP 1997 level database and Table A2 the sectors in the TFP time-series sectoral growth rate database. Table A3 shows the concordance between the two, the names of the 21 overlapping sectors, and their tradability descriptor.

\section{A.1.1 1997 TFP levels}

The construction of the 1997 GDDC TFP level databast 22 is described in Inklaar and Timmer (2008) (IT thereafter). The database is constructed for 30 OECD countries using an improved version of the methodology of Jorgenson and Nishmizu (1978) We use the output-based measure of TFP which IT argue better reflects technology differences than the two other value-added measures (see IT pp. 23).

TFP 1997 level estimates are constructed vis-à-vis the U.S. levels in two stages. First, symmetric Input-Output Tables and input PPPs are constructed for 45 subindustries. The second stage consists of two steps. First, PPPs for capital, labor and intermediate inputs for 29 industries (based on 45 sub-industries) are constructed using a price-variant of index number approach in Caves et al. (1982) known as the CCD method. These are used to implicitly derive quantities of all inputs and outputs. The second step, known as primal level accounting, sees industry comparative productivity levels constructed on the basis of input and output quantities in a bilateral Tornqvist model as in Jorgenson and Nishimizu (1978). Specifically, for sector $i$ in

\footnotetext{
${ }^{22}$ See http://www.rug.nl/research/ggdc/data/ggdc-productivity-level-database.

${ }^{23}$ The improvements include the use of sectoral IO measures that exclude intra-industry flows, the application of multilateral indices at the industry level, and the use of relative output prices from the production side and the use of the exogenous approach to capital measurement.
} 
country $j$ in 1997, IT estimate the level of sectoral TFP as:

$$
\ln A_{i, j} \equiv \ln T F P_{i, j}^{S O}=\ln \frac{Q_{i, j}^{S O}}{Q_{i, U S}^{S O}}-\hat{\nu}_{K} \ln \frac{Q_{i, j}^{K}}{Q_{i, U S}^{K}}-\hat{\nu}_{L} \ln \frac{Q_{i, j}^{L}}{Q_{i, U S}^{L}}-\hat{\nu}_{I I} \ln \frac{Q_{i, j}^{I I}}{Q_{i, U S}^{I I}}
$$

where $Q_{j}^{K}$ is a quantity index of capital services, $Q_{c}^{L}$ is a quantity index of labor services and $Q_{j}^{I I}$ is a quantity index of intermediate input services. $\hat{\nu}_{K}$ is the share of capital services in total costs averaged over the two countries: $\hat{\nu}_{K}=0.5\left(\nu_{j}^{K}+\nu_{j}^{U S}\right)$ where $\nu_{j}^{K} \equiv \frac{V_{j}^{K}}{V_{j}^{K}+V_{j}^{L}+V_{j}^{I T}}$ and $V_{j}^{K}$ is the nominal value of capital services. In order to facilitate quantity measure comparisons, $Q_{j}^{S O}=\frac{V_{j}^{S O}}{P P P_{j}^{S O}}$ where $V_{j}^{S O}$ is the nominal value of output in country $j$. Similarly for intermediate inputs $Q_{j}^{I I}$. For labor input $Q_{j}^{L}$, the same ratio measure is justified by the need to aggregate various labor types (high- vs. low-skill), and the construction of $P P P_{j}^{L}$ which is constructed based on relative wages. For capital input, $Q_{j}^{K}=\frac{\tilde{V}_{j}^{K}}{P P P_{j}^{K}}$ where $\tilde{V}_{j}^{K}$ is the ex-ante nominal compensation of capital $\tilde{V}_{j}^{K}=V_{j}^{K}-V_{j}^{R}$ where $V_{j}^{R}$ is "supra-normal profits" (see IT section 4.1 for a detailed discussion).

\section{A.1.2 TFP time series}

A European Commission-funded project, EU KLEMS data contains annual observations for 25 European countries, Japan and the US from 1970 onwards. The data is described in detail in O'Mahony and Timmer (2009, OT thereafter). We use KLEMS' Total factor productivity growth March 2011 update to the November 2009 release ${ }^{24}$. The TFP is estimated in the growth accounting approach as a measure of disembodied technological change $e^{25}$. The growth accounting in KLEMS proceeds under standard neoclassical assumptions of constant returns to scale and perfect competition ${ }^{26}$ allows a full decomposition of industry $i$ output:

$$
\begin{aligned}
\Delta \ln Y_{i t}= & \bar{\nu}_{i t}^{X} \bar{\omega}_{i t}^{E} \Delta \ln X_{i t}^{E}+\bar{\nu}_{i t}^{X} \bar{\omega}_{i t}^{M} \Delta \ln X_{i t}^{M}+\bar{\nu}_{i t}^{X} \bar{\omega}_{i t}^{S} \Delta \ln X_{i t}^{S} \\
& +\bar{\nu}_{i t}^{K} \bar{\omega}_{i t}^{I C T} \Delta \ln K_{i t}^{I C T}+\bar{\nu}_{i t}^{K} \bar{\omega}_{i t}^{N} \Delta \ln K_{i t}^{N} \\
& +\bar{\nu}_{i t}^{L} \Delta \ln L C_{i t}+\bar{\nu}_{i t}^{L} \Delta \ln H_{i t}+\Delta \ln B_{i t}^{Y}
\end{aligned}
$$

where $Y$ is output, $K$ is an index of capital service flows, $L$ is an index of labor service flows, $X$ is an index of intermediate inputs, $H$ is hours worked, $L C$ is labor

\footnotetext{
${ }^{24}$ See http://www.euklems.net/euk09ii.shtml

${ }^{25}$ Technical change embodied in new capital goods is excluded from TFP due to the KLEMS' use of quality-adjusted prices.

${ }^{26}$ Consequently, negative TFP growth can be observed in some service industries, which OT is a consequence of well-known measurement issues surrounding corporate reorganization and institutional changes (see Basu et al. 2004 and Hulten, 2001).
} 
composition ${ }^{27}$ and $B$ is an index of disembodied (Hicks-neutral) technological change. Intermediate inputs are further split into energy $(E)$, materials $(M)$ and services $(S)$, each with a respective period-average share $\bar{\omega}$ in total input costs. Each of the inputs $K, L, X^{E}, X^{M}, X^{S}$ is constructed as a Törnqvist quantity index of individual subtypes $\left(\Delta \ln I_{i t}=\sum_{l} \bar{\omega}_{l, i t}^{I} \Delta \ln I_{l, i t}\right) . \quad \bar{\nu}$ are two-period average shares of each input in the nominal output.

\section{A.1.3 Construction of the TFP level sectoral panel dataset}

The construction of TFP level sectoral panel dataset proceeds in four steps. First, the sectors in the 1997 cross-section dataset are matched to the sectors in the TFP growthrate dataset. Second, a level TFP series is constructed for each sector and country. Third, TFP level is expressed relative to EU12 average, to match the construction of the real exchange rate dataset as closely as possible ${ }^{28}$. Fourth, the sectors are aggregated into Traded and Nontraded aggregates using sectoral output data.

Let $A_{i j}$ be the 1997 GDDC sectoral-output and PPP based TFP of sector $i$ in country $j$, relative to the US. Let $B_{i j t}$ be the EU KLEMS sectoral-output and PPP based TFP index of sector $i$ in country $j$ and year $t$, re-scaled so that $B_{i, j, 1997}=$ $100 \forall i, j$. Both $A$ and $B$ are synchronized to the 21 sectors as in Table A3. Let also $B_{i, U S, t}$ be the TFP index for each sector in the US, also with the base of 100 in 1997. Then, sectoral TFP level $C_{i j t}$ is constructed as:

$$
C_{i j t}=\frac{A_{i j} B_{i j t}}{B_{i, U S, t}}
$$

and similarly for the EU15 aggregate:

$$
C_{i, E U 12, t}=\frac{A_{i, E U 12} B_{i, E U 12, t}}{B_{i, U S, t}}
$$

The TFP level index expressed vis-a-vis EU12. It is the ratio of (3) and (4):

$$
T F P_{i j t}=\frac{C_{i j t}}{C_{i, E U 12, t}}=\frac{A_{i j} B_{i j t}}{A_{i, E U 12} B_{i, E U 12, t}}
$$

The aggregate traded and nontraded TFP levels are computed as follows:

$$
T F P_{T, j, t}=\frac{\sum_{i \in T} \gamma_{i j, T} C_{i j t}}{\frac{1}{12} \sum_{j \in E U 12}\left(\sum_{i \in T} \gamma_{i, j, T} C_{i, j, t}\right)}
$$

\footnotetext{
${ }^{27}$ Labor composition is growth literature's measure of "labor quality" (see Jorgenson et al. 2005). It consists of labor characteristics such as educational attainment, age and gender.

${ }^{28}$ Only 12 of the EU15 countries have TFP data: Belgium, Germany, Spain, France, Ireland, Italy, the Netherlands, Austria, Finland, Sweden, Denmark and the United Kingdom.
} 


$$
T F P_{N, j, t}=\frac{\sum_{i \in N} \gamma_{i j, N} C_{i j t}}{\frac{1}{12} \sum_{j \in E U 12}\left(\sum_{i \in N} \gamma_{i, j, N} C_{i, j, t}\right)}
$$

where $\gamma_{i j, T}\left(\gamma_{i j, N}\right)$ is a 1997 sectoral output weight of sector $i$ in traded (nontraded) output of country $j$ (s.t., $\sum_{i} \gamma_{i j}=1 \forall j$ ). The agriculture sector is omitted from the analysis because of the EU's Common Agricultural Policy's distortion of many assumption used to calculate sectoral TFP measures.

Consequently, the relative productivity measure in Traded to Nontraded sectors is constructed as a ratio of (5) and (6). In our empirical analysis we always work with the logarithms of these constructed productivity measures.

\section{A.2 Real Exchange Rates}

We use a dataset on price levels from the Eurostat-OECD PPP Programme29, The dataset covers most European countries over the 1995-2009 period. The data are annual Price Level Indices, or PLI's. They give the price of the good category at a given time and for a given country, relative to the price in the reference country. The reference country is the EU 15 area 30 . PLI's are available for 146 consumer expenditure headings on goods and services. These are listed in Table 1. At any point of time $t$, PLI for good $i$ in country $j$ tells us how much more (or less) expensive good $i$ is in country $j$ than in the EU15.

Table 1 also illustrates the breakdown of goods between the categories "Traded" and "Non-traded". The criterion of this breakdown follows the categorization of goods into traded and non-traded in Table A2 of Crucini, et al. (2005). All goods with a positive trade share are categorized as "traded", and those with a zero trade share as "non-traded". Our data contains two types of services that are not in Crucini, et al. (2005): education (at different levels), and prostitution. While some some tertiary education engages international trade, the nature of price setting in this sector suggests that the trade has at most a negligible influence on the price of tertiary education. We categorize both as non-traded.

Composition of the consumption baskets differs across goods, countries, and time. We construct expenditure weights for each good, country, and year, using the expenditure data provided in the same Eurostat-OECD Programme. Specifically, for good

\footnotetext{
${ }^{29}$ Methodological manuals describing the dataset are available at: http://epp.eurostat. ec.europa.eu/portal/page/portal/product_details/publication?p_product_code= KS-RA-12-023 and http://epp.eurostat.ec.europa.eu/cache/ITY_OFFPUB/KS-BE-06-002/ EN/KS-BE-06-002-EN.PDF

${ }^{30}$ That is, Austria, Belgium, Denmark, France, Germany, Greece, Ireland, Italy, Luxembourg, the Netherlands, Spain, Sweden, Portugal, Finland, and the United Kingdom.
} 
$i$, country $j$ and year $t$, we construct a weight $\gamma_{i, j, t}=\frac{\exp p_{i, j, t}}{\sum_{i}^{146} \exp p_{i, j, t}}$ where $\exp$ is the local expenditure. We then construct an expenditure-weighted PLI's for all countries using $\gamma_{i, j, t}$.

Denoting $p_{i, j, t}$ as the log of a PLI, in year $t$, for a good $i$ in EU15 relative to country $j$, we calculate the log of the real exchange rate of country $j, q_{j, t}$, as the expenditure-weighted arithmetic average:

$$
q_{j, t}=\sum_{i=1}^{146} \gamma_{i, j, t} p_{i, j, t}
$$

Note that, in line with the literature, this measure is expressed such that an increase in $q_{j, t}$ is a real depreciation.

\section{A.3 Gross wages}

Database: Eurostat, National Accounts by 6 branches - aggregates at current prices Series name: nama_nace06_c

Indicator: D11, Gross wages and salaries. Millions or Euro. Total: all NACE activities.

Link: http://appsso.eurostat.ec.europa.eu/nui/show.do?dataset=nama_naced6_ c\&lang=en

\section{A.4 Unit Labor Costs}

Database: OECD.Stat, Unit labour costs Annual indicators

Series name: ULC_ANN

Sector: Total Economy

Measure: Level, ratio, or national currency

Link: http://stats.oecd.org/Index.aspx?DataSetCode=ULC_ANN

Unit Labor Costs are expressed relative to EU17 average, as provided by OECD.Stat.

\section{A.5 Weekly hours}

Database: Eurostat, Average number of usual weekly hours of work in main job, by sex, professional status, full-time/part-time and economic activity (NACE Rev. 1.1) - hours

Series names: lfsa_ewhuna for 1983-2008, and lfsa_eqhuna2 for 2008 onwards Indicator: Series selected for Total sex, Total worktime, Works status: Employed persons, NACE: All NACE activities 
Link: http://appsso.eurostat.ec.europa.eu/nui/show.do?dataset=lfsa_ewhuna\&lang= en

\section{A.6 Population}

Database: Eurostat, Population and employment - annual data

Series name: nama_aux_pem

Indicator: Total population. Unit: 1000 persons.

Link: http://appsso.eurostat.ec.europa.eu/nui/show.do?wai=true\&dataset= nama_aux_pem

\section{A.7 Construction of the labor supply shock}

As Appendix B explains, we use the difference between the hourly wage and the normalized employment to construct the labor supply shocks. For each country, $w-n$ is constructed as follows: $w$ is the log of the hourly wage. $n$ is the log of employment. Because our model assumes that countries are of the same size, we normalize $n$ by each country's population. The hourly wage $w$ is constructed as overall gross wages (millions of Euro) divided by total weekly hours worked. Weekly hours worked are constructed as a product of average weekly hours worked (annual panel) and the total employment. Employment $n$ is constructed in the same fashion. The EU12 value for $w^{*}-n^{*}$ is constructed by calculating the log EU12 hourly wage and subtracting from it the $\log$ EU12 employment.

\section{B Appendix: Model simulations}

The model has three different kinds of shocks in the Home country: productivity shocks in each of the two sectors, $A_{i, t}, i=H, N$, and shocks to the disutility of labor, $\chi_{t}$. There is also a Foreign country. We set Foreign shocks equal to zero, and then calibrate each of the Home country shocks using data relative to the EU12 set of countries. Shocks enter the model in relative terms, so this is equivalent to treating the EU12 as the Foreign country. Note that even though Foreign shocks are set to zero, Foreign variables are not constant because in equilibrium there is feedback from the Home to the Foreign country.

We calibrate the model by generating normally distributed random variables for nine artificial countries that have the same moments as the data. Specifically, the artificial data have the same means, serial correlation, and covariance matrix as the data. 
The data used to create the moments for traded and nontraded productivity are the same as the data used in our empirical work. There is no direct measure of labor supply shocks. However, in our model, under the calibration that the Frisch elasticity of labor supply is equal to one, the term that represents the random part of the log of the Home relative to the log of the Foreign disutility of labor, under complete markets, is given by: $\chi_{t}^{*}-\chi_{t}=w_{t}^{*}-n_{t}^{*}-\left(w_{t}-n_{t}\right)$. Note that the terms on the right side of the equation are not wages per unit of labor effort: $w_{t}$ and $w_{t}^{*}$ have that dimension. Instead, a term like $w_{t}-n_{t}$ is the log of wage per unit of labor effort squared. Again, this is the appropriate measure implied by the equilibrium conditions of the model when the Frisch elasticity equals one.

$w_{t}$ is the log of the hourly wage constructed as overall gross wage (millions of euros) divided by weekly hours worked per person. Weekly hours are constructed from Eurostat as the product of average weekly hours times total employment divided by population. Total employment is divided by total population to give a measure of total employment per person. Our model assumes the population of Home and Foreign is each one, but for different sized countries, total employment must be scaled by population to give employment per person. $w_{t}-n_{t}$ is the log of gross wage divided by the square of weekly hours worked per person.

Our regressions use annual data for 15 years, but we calibrate a period to be one quarter in the model. The length of the period matters particularly when considering the effects of price stickiness on the economy. Hence, we create artificial data for 60 quarters. We then aggregate the artificial data into annual data by taking quarterly averages in order to compare the statistics generated by the model to the data.

Here is how we translate the moments of the annual data into quarterly data for the model.

We suppose that the log of quarterly TFP (both traded and nontraded) as well as labor preference shocks follow first-order autoregressions:

$$
a_{t}^{q}-\bar{a}=\rho^{q}\left(a_{t-1}^{q}-\bar{a}\right)+u_{t}^{q}
$$

Annual productivity is the average of quarterly productivity: $A_{t}^{a}=\frac{1}{4}\left(A_{t}^{q}+A_{t-1}^{q}+\right.$ $\left.A_{t-2}^{q}+A_{t-3}^{q}\right)$. To a first-order approximation, around the point $E\left(\exp \left(a_{t}^{a}\right)\right)=E\left(\exp \left(a_{t}^{q}\right)\right)=$ $\exp (\bar{a})$, we have $a_{t}^{a}=\frac{1}{4}\left(a_{t}^{q}+a_{t-1}^{q}+a_{t-2}^{q}+a_{t-3}^{q}\right)$.

If we had quarterly observations on annual average data, we would find then that the annual data follow a process of:

$$
a_{t}^{a}-\bar{a}=\rho^{q}\left(a_{t-1}^{a}-\bar{a}\right)+e_{t},
$$


where $e_{t}=\frac{1}{4}\left(u_{t}^{q}+u_{t-1}^{q}+u_{t-2}^{q}+u_{t-3}^{q}\right)$. In fact, we have annual observations on annual data, which follow the process:

$$
a_{t}^{a}-\bar{a}=\rho^{a}\left(a_{t-4}^{a}-\bar{a}\right)+u_{t}^{a}
$$

where $\rho^{a} \equiv\left(\rho^{q}\right)^{4}$ and $u_{t}^{a} \equiv \frac{1}{4}\left(e_{t}+\rho^{q} e_{t-1}+\left(\rho^{q}\right)^{2} e_{t-2}+\left(\rho^{q}\right)^{3} e_{t-3}\right)$.

We then calculate the serial correlation of the artificial quarterly data using $\rho^{q}=\left(\rho^{a}\right)^{0.25}$. In a couple of cases, the estimated serial correlation coefficient for the productivity data was above 1.0. Our numerical model assumes stationary productivity, so in those cases we set $\rho^{q}=0.99$. The unconditional mean of the quarterly process is taken to be the same as the unconditional mean of the annual process.

Calibrating the variance of the quarterly shocks is more difficult. If the quarterly data followed an $\mathrm{AR}(1)$ with uncorrelated shocks, then the annual data should follow an $\operatorname{ARMA}(1,4)$ process, but we find that an $\mathrm{AR}(1)$ with serially uncorrelated shocks adequately captures the dynamics of the annual data. Hence, we treat the $e_{t}$ as being serially uncorrelated. When $\rho^{q}$ is close to one, it implies we should then set $\operatorname{var}\left(u_{t}^{q}\right)=\operatorname{var}\left(u_{t}^{a}\right)$.

We calibrate the AR(1) coefficient and unconditional mean for each exogenous random variable (for logs of traded and nontraded productivity and for logs of labor supply shocks) as above from the annual data. We draw the shocks for the artificial data from a Normal multivariate distributions (for each of the three exogenous random variables) for the nine Eurozone countries with the three variance-covariance matrices calibrated as described above to the three variance-covariance matrices estimated from the data.

\section{B.1 The role of measurement error in the the regression of $q$ on $q_{n}$.}

In section 3, we noted that the coefficient on $q_{n}$ in the regression of $q$ on $q_{n}$ in Table 4a was lower than that which comes out of the simulated regressions in Table 9a. This may be due to the fact that non-traded distribution services are not accurately measured by the observed price of non-traded goods. To see this, take the following example.

Let us use the notation $p_{S}$ and $p_{S}^{*}$ for the true prices of non-traded distribution services. Assume that $p_{S}=p_{N}+u$, where $u$ is some exogenous disturbance that makes the price of distribution services different from the general price of non-traded goods and services. Assume that $p_{N}$ and $u$ are uncorrelated. Then (9) becomes

$$
q=(1-\gamma \kappa)\left(p_{N}^{*}-p_{N}\right)+\gamma(1-\kappa)\left(u^{*}-u\right)
$$


In addition, using the same conditions, we have

$$
q_{n}=\left(p_{N}^{*}-p_{T}^{*}-\left(p_{N}-p_{T}\right)\right)=\kappa\left(p_{N}^{*}-p_{N}\right)-(1-\kappa)\left(u^{*}-u\right)
$$

Using (24) in 23) we arrive at the 'true' relationship between $q$ and $q_{n}$ given by:

$$
q=\frac{(1-\gamma \kappa)}{\kappa} q_{n}+\frac{(1-\kappa)}{\kappa}\left(u^{*}-u\right)
$$

Hence, using (24) and (25), our estimate of the slope coefficient in the regression of $q$ on $q_{n}$ will be

$$
\frac{\operatorname{cov}\left(q, q_{n}\right)}{\operatorname{var}\left(q_{n}\right)}=\frac{(1-\gamma \kappa)}{\kappa}-\frac{(1-\kappa)^{2}}{\kappa} \frac{\operatorname{var}\left(u^{*}-u\right)}{\operatorname{var}\left(q_{n}\right)}
$$

The coefficient estimate is biased downwards from $\frac{1-\gamma \kappa}{\kappa}$. The bias is larger, the larger is the share of the non-traded distribution service.

\section{Further discussion of Eurostat data procedures}

Here we quote extensively, but selectively, from the Eurostat-OECD PPP manual, Chapter 4, to convey a sense of the efforts that are put in to make the price data comparable across countries. We say that our quotations are 'selective' because the manual itself is over 400 pages long, covering far too many issues for us to mention here. The data on prices comes from 6-monthly survey. The first set of prices is collected in April to May, and the second set in October to November each year.

The composition of a basket of goods within each basic heading (e.g., "rice") is "defined as one that accounts for a significant share of a country's expenditure within a basic heading because this means that its price level will be close to country's average price level for all products in the basic heading.".

The manual argues this data is specifically designed for inter-national comparisons, and is better suited for that purpose than CPI data (section 4.9 on page 63).

"Faced with such an array [.. of goods within each basic heading ...], selecting a subset of products for a basic heading that can be priced over a number of countries is clearly going to be difficult, much more difficult than it is to select the products to be priced at the elementary level of a consumer price index (CPI) within a single country. There, within broad guiding parameters, the selection can be left to the price collector whose choice may differ from outlet to outlet providing it does not change over time. This initiative cannot be allowed to price collectors collecting prices for Eurostat and OECD comparisons because they are spatial comparisons."

Regarding the 'representativeness' of prices that are surveyed: 
"Equal representativity or 'equi-representativity' - does not require all participating country to price the same number of representative products for a basic heading. As explained in Chapter 7, the method used by Eurostat and the OECD to calculate the PPPs for a basic heading ensures that any imbalance between countries in the number of representative products priced does not produce biased price relatives. The method requires that each participating country price at least one representative product per basic heading. This is a necessary condition to calculate unbiased PPPs, but it is not a sufficient condition to obtain reliable PPPs. For this, each participating country should price that number of representative products which is commensurate with the heterogeneity of the products and price levels within the basic heading and with the importance of its own expenditure on the basic heading."

The manual has this to say about products included in the survey:

"For a product to be included on the product list at least one other country, besides the proposing country, has to agree to price it. This is a minimum condition. It is preferable that more than one country agrees to price it. ... Not all proposals made by countries will be accepted."

Much effort is made to insure goods that are priced are comparable across countries:

"At the start, each country group makes its product selection independently of the other groups and the same products will not necessarily be selected by all groups. Eurostat and the OECD cover all participating countries in a single comparison irrespective of group. It is necessary to make sure before prices are collected that countries can be compared not only with countries in their group but also with countries in the other groups. This is achieved with overlap products - that is, products that are common to more than one group. Overlap products are identified and included after the group product lists have been finalized. The process is described later in the chapter."

"The issue of heterogeneity raised earlier is partly eased by the way basic headings are defined in the Eurostat-OECD expenditure classification. Definitions list the products covered by the basic headings. For example, 'other bakery products' include 'crispbread, rusks, toasted bread, biscuits, gingerbread, wafers, waffles, crumpets, muffins, croissants, cakes, tarts, pies, quiches and pizzas'. The lists are not exhaustive, but they are sufficiently extensive to allow the more heterogeneous basic headings to be subdivided into smaller and more homogeneous product groups. Breaking a basic heading down into a more manageable framework facilitates both product selection and coverage. In anticipation of this, the lists for the more heterogeneous 
basic headings arrange products in sets. For example, the list for the basic headings covering clothing identifies four sets or subgroups:

- capes, overcoats, raincoats, anoraks, parkas, blousons, jackets, trousers, waistcoats, suits, costumes, dresses, skirts, etc.;

- shirts, blouses, pullovers, sweaters, cardigans, shorts, swimsuits, tracksuits, jogging suits, sweatshirts, T-shirts, leotards, etc.;

- vests, underpants, socks, stockings, tights, petticoats, brassires, knickers, slips, girdles, corsets, body stockings, etc.;

- pyjamas, night-shirts, night dresses, housecoats, dressing gowns, bathrobes, etc."

Following the selection of representative baskets (after Eurostat agrees on the proposals, following negotiations), individual countries collect the actual prices.

"Price collection is the responsibility of the participating countries. On receipt of the final product list for their group, countries are required to price it at a sample of outlets which, even if selected purposively, reflects the purchasing patterns of households. They are expected to price as many items on the product list as comparability and availability allow. After the price survey, countries are required to edit the prices collected for outliers using the software supplied by Eurostat. After making the necessary corrections, they report the individual price observations, the average survey prices and a report on the survey to their group leader. The country reports on the survey, together with the individual price observations, assist the group leader with the editing of the average survey prices.

The goods and services to be priced may differ from survey to survey, but all the surveys share a common objective namely, that each participating country prices a set of internationally comparable products across a representative sample of outlets. Clearly, if this objective is to be met, the price surveys need to be carefully planned and prepared by their national organizers. Before starting price collection, participating countries are expected to carry out a number of tasks. These involve:

- selecting the outlets that are to be visited by price collectors and contacting the outlets selected to explain why they are to be visited;

- preparing pricing materials and other documentation for price collectors (product specifications, survey guidelines, price reporting forms, outlet codes and co-ordinates, schedule of visits, identification and letters of introduction, etc.), 
including the translation of product specifications and survey guidelines into the national language if necessary;

- identifying which specifications on the final group product list are to be priced and, in the case of generic specifications, which brands are to be priced (if these tasks are not left for the price collectors to do themselves);

- holding a meeting with price collectors to clarify the pricing and supporting materials prepared and issues such as how many items per basic heading, how many prices per item, etc.

The tasks are important because they avoid nonresponse and reduce non-sampling error."

On outlet selection:

"CPIs measure price changes over time by repeatedly pricing the same product at the same outlet, thereby keeping the service element constant. For practical reasons this approach has not been followed in international comparisons of GDP. The 'potato is a potato' rule is applied instead. Each product specified is treated as being homogeneous regardless of where it is priced. If, when averaging the prices collected for the product, no account is taken of the different service elements of the outlets at which they were observed, the average price is likely to be too high or too low. To avoid this, countries participating in Eurostat and OECD comparisons are required to select outlets so that the selection mirrors consumer purchasing patterns at various outlet types for the products being priced. If consumers buy 50 per cent of their clothing from departmental stores, 30 per cent from supermarkets and 20 per cent from specialist shops, then a sample of ten outlets would include five departmental stores, three supermarkets and two specialist shops."

On the number of price observations for each good in each survey:

"The number of prices to be collected for each product could be decided using random sampling techniques. Providing the price variation $(C V)$ of the product is known and the desired degree of accuracy $(S E)$ is specified, sample size $(N)$ is determined by $\left[t^{2} C V^{2} / S E^{2}\right]$, where $t$ is Student's t and which is here assumed to equal 2 at 0.95 probability. For example, if it is known from the last time the price survey was conducted that the coefficient of variation for the average price of a product is 20 per cent and the level of precision sought in the forthcoming survey is 10 per cent, the sample size should be 16 . With the same price variation and a precision level of 5 per cent, the sample size should be 64 . In other words, a twofold increase in accuracy requires a fourfold increase in sample size. ... A coefficient of variation of 20 per cent 
is high. A coefficient of variation higher than 20 per cent indicates that either the product description was too broad or that the price collection was faulty. In general, price differences for a product within a country should not be more than 10 to 50 per cent, a coefficient of variation of approximately 5 to 15 per cent. Tight specifications usually have a lower coefficient of variation than loose specifications. On this basis, rough upper limits can be assigned to the coefficients of variation for specifications that are brand specific (10 per cent), specifications that cover well-known brands (15 per cent) and specifications that are brandless (20 per cent). Assuming a level of precision of 10 per cent, which is both reasonable and acceptable, application of $\left[t^{2} C V^{2} / S E^{2}\right]$ gives sample sizes of around 5 for brand specific specifications, of around 10 for well-known brand specifications and between 15 to 20 for brandless specifications."

The prices are usually collected in the capital city (for most countries). Consequently, countries need to provide a "spatial adjustment factor" that helps to convert those prices to the "national average price".

There is a temporal adjustment to get an annual price uses CPI monthly data. This is done with "temporal adjustment factors", extracted from CPI:

"Participating countries extract the temporal adjustment factors from their CPI data base. COICOP38 is the classification underlying the CPIs of most participating countries. And, as explained in Chapter 3, it is as well the classification underlying the breakdown of individual consumption expenditure by households in the EurostatOECD classification of final expenditure on GDP. The correspondence between CPI sub-indices and basic headings is therefore generally high. But when there is no exact match, participating countries are expected to select a sub-index, or an aggregation of subindices, that closely approximates the basic heading in question. CPI sub-indices are usually more detailed than basic headings and often they can be aggregated specifically for a basic heading." 


\section{Table A1. Sectors in the GGDC 1997 TFP level database}

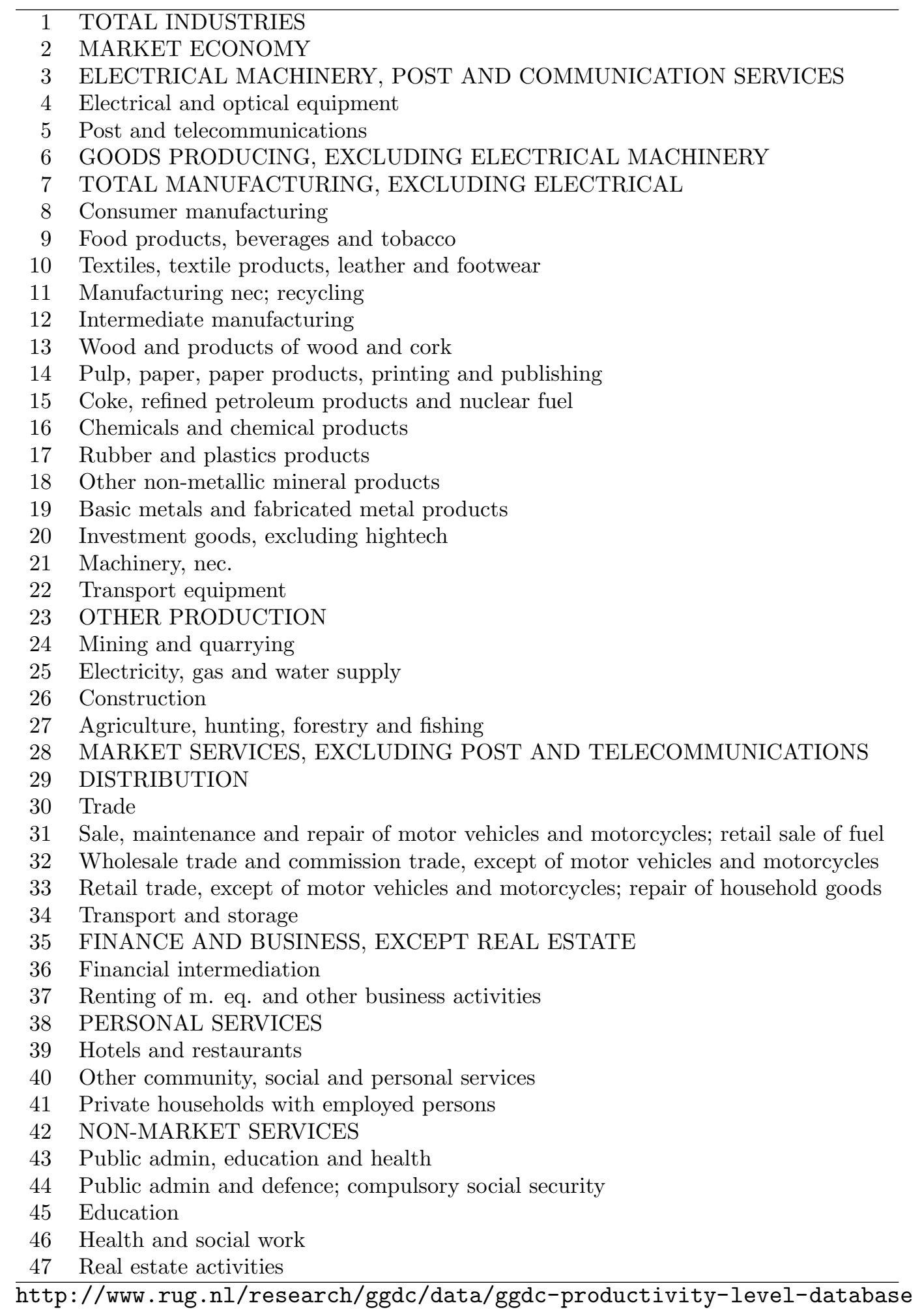


Table A2. Sectors in the March 2009 edition of the KLEMS TFP time-series database

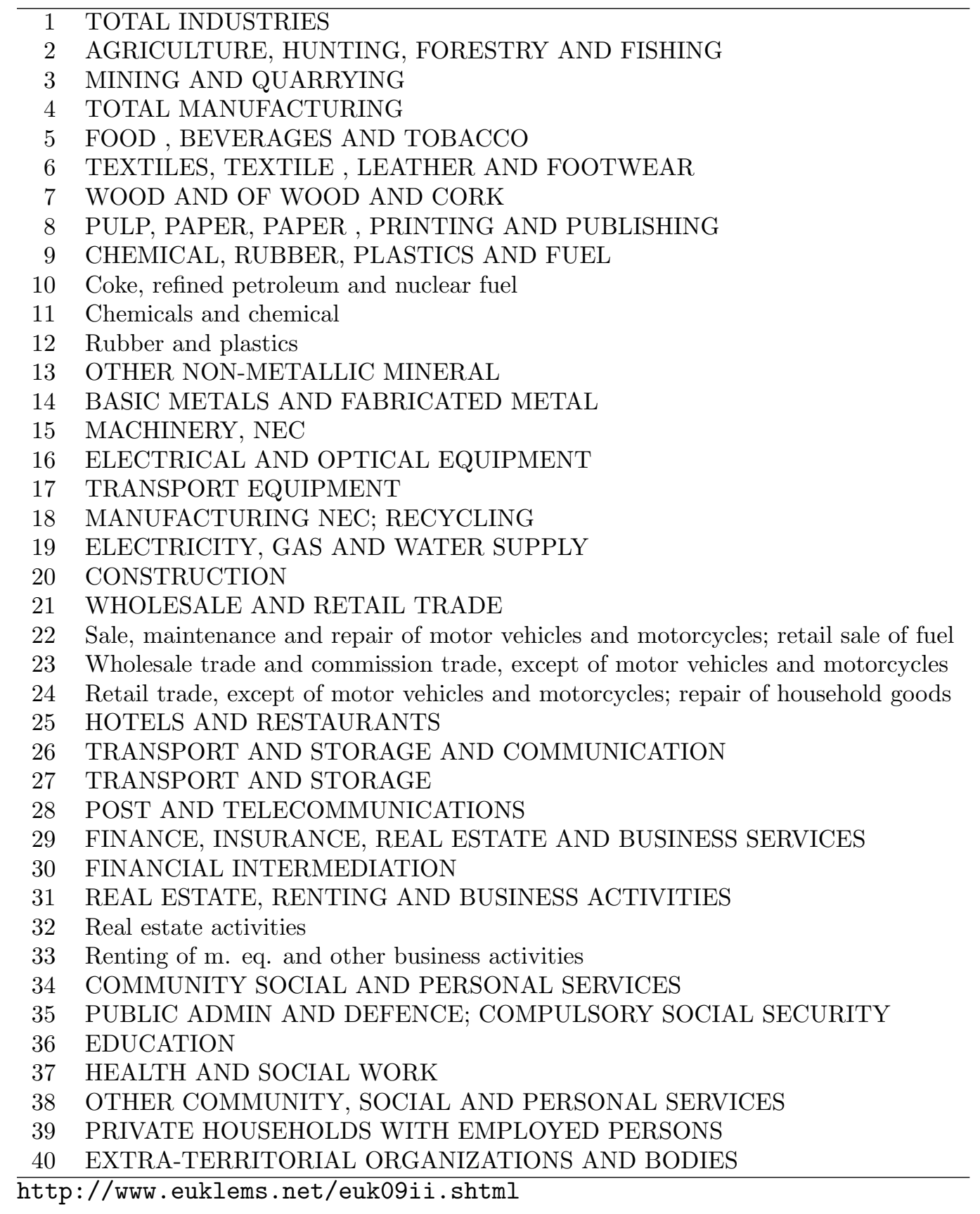


Table A3. Sectoral concordance

\begin{tabular}{|c|c|c|c|c|}
\hline & $\begin{array}{c}\text { GGDC } \\
\text { sector ID }\end{array}$ & $\begin{array}{c}\text { KLEMS } \\
\text { sector ID }\end{array}$ & Tradability & Names of sectors \\
\hline 1 & 27 & 2 & $\mathrm{~T}$ & Agriculture, hunting, forestry and fishing \\
\hline 2 & 24 & 3 & $\mathrm{~T}$ & Mining and quarrying \\
\hline 3 & 9 & 5 & $\mathrm{~T}$ & Food, beverages and tobacco \\
\hline 4 & 10 & 6 & $\mathrm{~T}$ & Textiles, textile, leather and footwear \\
\hline 5 & 13 & 7 & $\mathrm{~T}$ & Wood and of wood and cork \\
\hline 6 & 14 & 8 & $\mathrm{~T}$ & Pulp, paper, paper, printing and publishing \\
\hline 7 & 16 & 9 & $\mathrm{~T}$ & Chemical, rubber, plastics and fuel \\
\hline 8 & 18 & 13 & $\mathrm{~T}$ & Other non-metallic mineral \\
\hline 9 & 19 & 14 & $\mathrm{~T}$ & Basic metals and fabricated metal \\
\hline 10 & 21 & 15 & $\mathrm{~T}$ & Machinery, nec \\
\hline 11 & 4 & 16 & $\mathrm{~T}$ & Electrical and optical equipment \\
\hline 12 & 22 & 17 & $\mathrm{~T}$ & Transport equipment \\
\hline 13 & 11 & 18 & $\mathrm{~T}$ & Manufacturing nec; recycling \\
\hline 14 & 25 & 19 & $\mathrm{~N}$ & Electricity, gas and water supply \\
\hline 15 & 26 & 20 & $\mathrm{~N}$ & Construction \\
\hline 16 & 29 & 21 & $\mathrm{~N}$ & Wholesale and retail trade \\
\hline 17 & 39 & 25 & $\mathrm{~N}$ & Hotels and restaurants \\
\hline 18 & 34 & 27 & $\mathrm{~N}$ & Transport and storage \\
\hline 19 & 5 & 28 & $\mathrm{~N}$ & Post and telecommunications \\
\hline 20 & 36 & 30 & $\mathrm{~N}$ & Financial intermediation \\
\hline 21 & 37 & 31 & $\mathrm{~N}$ & Real estate, renting and business activities \\
\hline
\end{tabular}

